\title{
Site U1395
}

\author{
Expedition 340 Scientists $^{2}$
}

\section{Chapter contents}

Background and objectives. ......... 1

Operations.................. 1

Lithostratigraphy............... 2

Paleontology and biostratigraphy .......5

Geochemistry ...............6

Physical properties . . . . . . . . . . . 7

Paleomagnetism ............... 9

Downhole logging . . . . . . . . . . 10

References................. 12

Figures................. 14

Tables..................... 36

'Expedition 340 Scientists, 2013. Site U1395. In Le Friant, A., Ishizuka, O., Stroncik, N.A., and the Expedition 340 Scientists, Proc. IODP, 340: Tokyo (Integrated Ocean Drilling Program Management International, Inc.).

doi:10.2204/iodp.proc.340.105.2013

'Expedition 340 Scientists' addresses.

\section{Background and objectives}

Integrated Ocean Drilling Program (IODP) Site U1395 (proposed Site CARI-04D; $16^{\circ} 29.60^{\prime} \mathrm{N}, 61^{\circ} 57.09^{\prime} \mathrm{W} ; 1191$ meters below sea level [mbsl]) is located between Guadeloupe and Montserrat (Fig. F1).

According to the site survey data, Site U1395 is located beside Deposit 2. Seismic reflection profiles indicated that drilling at Site U1395 could penetrate a succession of hemipelagic sediment and turbidites. The proposed total depth for this site was 244 meters below seafloor (mbsf).

The objective for Site U1395 was to characterize the sedimentation processes related to volcanic activity in the Bouillante-Montserrat half graben. We planned to drill through hemipelagic sediment, turbidites, and tephra to retrieve a complete record of sediment. Work around the Canary Islands has shown that distal volcaniclastic turbidites generated by collapse events can be used to study the gross character of landslide emplacement (Wynn and Masson, 2003; Hunt et al., 2011). Results from Ocean Drilling Program (ODP) Hole 1223A off Hawaii identified the association of several turbiditic deposits with landslides, showing that the Koolau Volcano collapsed repeatedly and that landslides constituted a greater risk than previously thought (Garcia et al., 2006). Analysis of cores taken during the JCR123 cruise suggests that distal turbidites associated with Montserrat provide a record of all main pyroclastic flow events that entered the ocean during the current eruptive phase (since 1995). Information from these cores also records the waxing and waning phases of individual dome collapses (Trofimovs et al., 2006). Turbidites in cores recovered from this site should therefore provide a record of dome and flank collapses. With the retrieved material, it will also be possible to better constrain the long-term sedimentation rate in the northern part of the arc.

\section{Operations}

\section{Transit to Site U1395}

After a $10 \mathrm{nmi}$ transit from Site U1394 in cruise mode, the vessel arrived at Site U1395. The vessel stabilized over Site U1395 at $0258 \mathrm{~h}$ on 13 March 2012. All times reported in this volume are given in ship local time, which was Universal Time Coordinated (UTC) $-4 \mathrm{~h}$. The position reference was a combination of GPS signals and a single acoustic beacon. The positioning beacon was deployed at $1030 \mathrm{~h}$ on 13 March. At the end of operations at Site 
U1395, the beacon was sent an acoustic command to release. Although it indicated that it had released, the beacon failed to surface and was declared lost.

\section{Site U1395}

Two holes were cored at Site U1395 (Table T1). The original plan called for two holes cored to $244 \mathrm{mbsf}$. Because coring was challenging and took longer than we originally anticipated, the first hole (U1395A) was only drilled to $231.3 \mathrm{mbsf}$. The second hole (U1395B) was only drilled to 203.3 mbsf because of time constraints. Hole U1395B was successfully logged with both the Formation MicroScanner (FMS)-sonic and triple combination (triple combo) logging strings. Fifty-three cores were recorded for the site. The extended core barrel (XCB) was deployed 23 times, and the advanced piston corer (APC) was deployed 30 times. The interval cored with the XCB was $189.7 \mathrm{~m}$ with a recovery of only $32.02 \mathrm{~m}$ of core $(17 \%)$. The interval cored with the APC was $244.9 \mathrm{~m}$ with a recovery of $251.80 \mathrm{~m}$ of core (103\%). Overall recovery for Site U1395 was 65\%.

\section{Hole U1395A}

The vessel arrived at Site U1395 and was in position at $0258 \mathrm{~h}$ on 13 March 2012. After an uneventful pipe trip, the top drive was picked up and the bit was spaced out to spud Hole U1395A. The hole was spudded at $0852 \mathrm{~h}$. Seafloor depth was calculated from the length of the first core: 1212.4 meters below rig floor (mbrf; $1200.9 \mathrm{mbsl}$ ). Orientation was performed with the FlexIt tool on the first nine cores with good results. Nonmagnetic core barrels were used for APC coring for Cores 340-U1395A-2H through $9 \mathrm{H}$. APC refusal in Hole U1395A came on Core $15 \mathrm{H}$ at 120.8 mbsf. The entire piston coring sequence was punctuated by frequent partial strokes. Cores $11 \mathrm{H}$ and $12 \mathrm{H}$ required drilling over to release them from the formation. The XCB system was then deployed, and coring continued through Core 28X without problems but with generally poor recovery. Fifteen piston cores were taken over a $120.8 \mathrm{~m}$ interval with a total recovery of $124.29 \mathrm{~m}$ of core. Thirteen XCB cores were cut over a $110.5 \mathrm{~m}$ interval with a recovery of $19.99 \mathrm{~m}$ of core. Overall core recovery for Hole U1395A was $144.18 \mathrm{~m}$ for the $231.3 \mathrm{~m}$ interval $(62 \%)$. After the completion of XCB coring, the top drive was set back and the bit cleared the seafloor at $1800 \mathrm{~h}$ on $14 \mathrm{March}$, ending Hole U1395A. The total time spent on Hole U1395A was 39 h.

\section{Hole U1395B}

After clearing the seafloor from Hole U1395A, the vessel was offset $20 \mathrm{~m}$ east and Hole U1395B was spudded at $1930 \mathrm{~h}$ on 14 March 2012. Seafloor depth was calculated from the mudline recovery: $1211.6 \mathrm{mbrf}$ (1200.2 mbsl). Nonmagnetic core barrels were used for APC coring for Cores 340-U1395B-2H through $10 \mathrm{H}$. APC refusal was encountered during Core $15 \mathrm{H}$ at 124.1 mbsf. The entire piston coring sequence was punctuated by frequent partial strokes. Cores $10 \mathrm{H}-$ $12 \mathrm{H}$ required drilling over to release them from the formation. The XCB system was then deployed, and coring continued through Core $25 \mathrm{X}$ without problems but with generally poor recovery. The Sediment Temperature Tool (SET) was deployed after Core 17X. Although the deployment seemed flawless, a seal within the tool leaked during deployment and no data was recovered from the tool. Fifteen piston cores were taken over a $124.1 \mathrm{~m}$ interval with a total recovery of $127.51 \mathrm{~m}$ of core. Ten XCB cores were cut over a $79.2 \mathrm{~m}$ interval with a recovery of $12.03 \mathrm{~m}$ of core. Overall core recovery for Hole U1395B was $140.21 \mathrm{~m}$ for the $203.3 \mathrm{~m}$ interval (69\%). At the conclusion of coring, Hole U1395B was conditioned with a 25 bbl high-viscosity mud sweep and displaced with $85 \mathrm{bbl}$ of $10.5 \mathrm{ppg}$ mud for logging. The drill string was then pulled back, the top drive was set back, the bit was set at 82.3 mbsf, and the pipe was hung from the blocks. The Schlumberger wireline was then rigged up for logging, and the triple combo was deployed. Two successful passes were made to 201.3 mbsf. There was some difficulty getting the tool string back into the drill string, but after several attempts the tool string entered the drill string and was pulled back to surface and rigged down. The FMS-sonic tool string was then picked up. The tool string was run to $200.4 \mathrm{mbsf}$, and two passes were made over the length of the open hole. The tool string was then pulled back to the surface and rigged down. The knobbies were laid out, and the drill string was pulled from the hole. The bit cleared the rotary table at $1930 \mathrm{~h}$, and the drill floor was secured at $2000 \mathrm{~h}$, ending Site U1395 and Hole U1395B. The vessel then proceeded underway to Site U1395. The total time spent on Hole U1395B was $50 \mathrm{~h}$.

\section{Lithostratigraphy}

The lithostratigraphy of Site U1395 consists of nine units (A-I). Each unit generally consists of various combinations of hemipelagic muds, turbidite sands and muds, and volcanic ash. Each lithology is described in detail in "Lithostratigraphy" in the "Site U1394" chapter (Expedition 340 Scientists, 2013b).

As at Site U1394, boundaries for each of the lithostratigraphic units are defined by abrupt or gradational changes in the abundance of lithologies and by distinctive marker horizons such as basaltic tephra fall and unusually thick turbidites. 


\section{Unit A}

Depths: Hole U1395A = 0-12 mbsf, Hole U1395B = 0-12 mbsf

Unit A at Site U1395 is similar to Unit A described for Holes U1394A and U1394B and consists mostly of hemipelagic sediment interbedded with a variety of volcaniclastic and mixed bioclastic-volcaniclastic turbidites. At Site U1395, Unit A extends from the seafloor to $\sim 12$ mbsf. This unit has been divided into five subunits (A-1 to A-5).

\section{Subunit A-1}

Subunit A-1 extends from the seafloor to $10 \mathrm{~cm}$ (Hole U1395A) or $21 \mathrm{~cm}$ (Hole U1395B) and contains (in Hole U1395B only) a series of three turbidite layers separated by thin muddy horizons. No distinction could be made between the three turbidites. These layers are considered to be products from the recent eruptions of the Soufrière Hills Volcano, Montserrat. All three turbidites in Hole U1395B grade from very coarse to fine sand. The base of the sequence in Hole U1395B is marked by an erosive boundary.

\section{Subunit A-2}

Subunit A-2 contains a sequence of predominantly mixed bioclastic-volcaniclastic turbidites separated by as much as $30 \mathrm{~cm}$ of hemipelagic sediment. In Hole U1395A, the fourth turbidite layer is $\sim 100 \mathrm{~cm}$ thick and contains more volcaniclastic material toward its base. In Hole U1395B, the equivalent layer is $<10 \mathrm{~cm}$ thick but still contains a significant proportion of volcaniclastic material, although it appears to be concentrated more toward the top of the turbidite. Below this, another one (Hole U1395B) or three (Hole U1395A) turbidites are found. All of the intervening hemipelagic mud is slightly to moderately bioturbated. The total thickness of this unit varies from $1.2 \mathrm{~m}$ in Hole U1395B to $3.6 \mathrm{~m}$ in Hole U1395A.

\section{Subunit A-3}

In Hole U1395B, Subunit A-3 consists of $\sim 1.5 \mathrm{~m}$ of moderately bioturbated, mottled, and banded hemipelagic mud. In Hole U1395A, this unit is only $32 \mathrm{~cm}$ thick.

\section{Subunit A-4}

Below Subunit A-3, as much as $1 \mathrm{~m}$ of stacked mixed bioclastic-volcaniclastic turbidites is present; these turbidites form Subunit A-4. In Hole U1395B, which contains the thickest sequence, some of the upper turbidites are laminated, whereas the lowest turbidite in the sequence measures $60 \mathrm{~cm}$ thick and contains a zone of dispersed felsic pumice at its base. This pumice-rich horizon is not seen in any of the turbidite packages in Hole U1395A.

\section{Subunit A-5}

The final sequence in Unit A, Subunit A-5, consists of a thick package of hemipelagic mud and various mixed bioclastic-volcaniclastic and volcaniclastic turbidites. Toward the base of this unit, particularly in Hole U1395A, two $2 \mathrm{~cm}$ thick coarse sand beds are found. These beds are normally graded and likely represent the distal extent of basaltic ash falls from the $138 \mathrm{ka}$ eruption of the South Soufrière Hills Volcano on Montserrat. The basaltic ash falls were also seen at Site U1394, where they consisted of thicker and coarser scoriaceous layers.

\section{Unit B}

Depths: Hole U1395A = 12-18 mbsf, Hole U1395B = 12-16.4 mbsf

Unit B extends from 12 to $16-18$ mbsf. The top of this unit is measured from the first occurrence of a thick sequence of stacked volcaniclastic turbidites, each $>1 \mathrm{~m}$ thick and exhibiting normal grading from very coarse to very fine sand. The matrix of these turbidites is rich in both dense and vesicular lava, as well as crystals (pyroxenes, amphiboles, and feldspars). Little to no carbonate could be identified in these turbidites. Occasionally, larger clasts $(\leq 2 \mathrm{~cm})$ of more pumiceous material were present. The sequence of stacked turbidites is much better developed in Hole U1395A, where the individual layers range in thickness from $<10 \mathrm{~cm}$ to $>1.5 \mathrm{~m}$.

\section{Unit C}

Depths: Hole U1395A $=18-18.7$ mbsf, Hole $\mathrm{U} 1395 \mathrm{~B}=16.4-17 \mathrm{mbsf}$

Unit $C$ consists of a $65 \mathrm{~cm}$ thick layer of hemipelagic sediment sandwiched between the two thick turbidite packages of Units B and D.

\section{Unit D}

Depths: Hole U1395A $=18.7-20$ mbsf, Hole $\mathrm{U} 1395 \mathrm{~B}=17-20 \mathrm{mbsf}$

Unit D ranges from $\sim 17$ to 20 mbsf and consists of a second thick sequence of stacked volcaniclastic turbidite beds. As with Unit B, the sequence is better developed in Hole U1395A, where several thin turbidites are found. Typically, the turbidites in Hole U1395A are similar to those seen in Unit B of Hole U1395A, containing abundant granules of andesitic lava in a crystal-rich matrix. In Hole U1395B, however, these turbidites appear different, as they are 
rich in pumice. Only two turbidites were identified at this level in Hole U1395B, and they were both $\sim 1.5 \mathrm{~m}$ thick. These two turbidites are rich in large (1-4 cm diameter) pumice clasts, which are dispersed throughout the matrix of each turbidite. There appears to be no grading or sorting of the pumice clasts in either turbidite. The base of Unit D is marked by the beginning of a sequence of hemipelagic sediment.

\section{Unit E}

Depths: Hole U1395A = 20-63 mbsf, Hole U1395B = 20-63 mbsf

Unit $\mathrm{E}$ extends from 20 to $63 \mathrm{mbsf}$ and contains principally muddy hemipelagic sediment, within which are intercalated a small number of relatively thin sandy turbidites. The turbidite sand can be volcaniclastic, bioclastic, or mixed in character and ranges in thickness from a few centimeters to a few meters. Additionally, several volcanic fine sand layers are identified in this unit. A $70 \mathrm{~cm}$ thick pumice-rich, clast-supported deposit occurs at 43 mbsf in Hole U1395B. Pumice is abundant (40\%-75\%) in this layer. This deposit lacks reworked carbonate and might represent an unusually thick pumice-fallout deposit. Two other relatively thick $(15-22 \mathrm{~cm})$ well-sorted pumice-rich fallout deposits occur at 19-20 mbsf in the upper part of Unit E.

\section{Unit F}

Depths: Hole U1395A = 63-82 mbsf, Hole U1395B = 63-82 mbsf

Unit $\mathrm{F}$ extends from 63 to $82 \mathrm{mbsf}$ and starts at a thick set of stacked turbidites with little or no intervening hemipelagic mud. This unit is divided into three subunits (F-1 to F-3).

\section{Subunit F-1}

Subunit F-1 is composed of a dark, thick homogeneous turbidite ( $>6 \mathrm{~m}$ thick) made of mixed bioclasticvolcaniclastic material. The majority of this turbidite is ungraded (fine to medium sand), with normal grading occurring only in the uppermost part. This turbidite sequence is $4 \mathrm{~m}$ thick in Hole U1395A and $2 \mathrm{~m}$ thick in Hole U1395B.

\section{Subunit F-2}

Subunit F-2 is mainly composed of hemipelagic sediment with intercalated sandy bioclastic or volcaniclastic layers. These layers are massive to normally graded, changing from very fine to medium sand. Some of these layers correspond to thin bioclastic or volcaniclastic turbidites, whereas other layers are dark in color, a few centimeters thick, and composed dominantly of crystals and a few lava and scoria fragments. We interpret these thin layers as tephra fallout deposits.

\section{Subunit F-3}

Subunit F-3 is composed of a thick volcaniclastic turbidite deposit, 3 to $3.5 \mathrm{~m}$ thick, which occurs at $~ 70$ 75 mbsf in Holes U1395A and U1395B. This turbidite consists of massive medium sand and contains a concentration of poorly vesiculated white pumice at the top. The matrix is composed of crystals (70\%), lava clasts $(<1 \%)$, pumice $(20 \%)$, and carbonates $(10 \%)$. No amphibole is observed in the matrix, although it is present in the pumice. However, a few green clinopyroxenes are identified in the matrix.

\section{Unit G}

Depths: Hole U1395A $=82-113$ mbsf, Hole $\mathrm{U} 1395 \mathrm{~B}=82-113 \mathrm{mbsf}$

Unit $G$ extends from 82 to 113 mbsf and is divided into two subunits (G-1 and G-2).

\section{Subunit G-1}

Subunit G-1 is composed of hemipelagic sediment in which are intercalated numerous volcaniclastic sand layers. It is distinguished from overlying Subunit F-3 by a greater abundance of hemipelagic sediment. The majority of sand layers (which are a few centimeters thick) are massive to normally graded from medium to very fine sand and composed dominantly of crystals, lava clasts, and scoria. Plagioclase is the dominant phase. Pyroxene is also present, whereas amphibole is rare. Amphibole appears only in few layers (without clinopyroxene). These layers are likely tephra fallout deposits originating from the volcanoes in the central part of Guadeloupe. Tephra fallout deposits are particularly abundant between 90 and 100 mbsf (Cores 340-U1395A-12H and 340U1395B-12H). Thicker sand layers correspond to turbidites. These turbidites are rare in Hole U1395A and are dominantly made of volcaniclastic material. In Hole U1395B, a succession of volcaniclastic turbidites occurs at the top of Subunit G-1. One of the turbidites (at the top of the sequence) is $5.3 \mathrm{~m}$ thick, massive, medium to coarse-grained sand composed of $90 \%$ volcaniclastic material (60\% crystals and 30\% lava) and $10 \%$ bioclastic material. A few bioclasts are observed (pteropods, otoliths, and spongy spicules) in this turbidite.

\section{Subunit G-2}

In Holes U1395A and U1395B, the hemipelagic sediment located at the base of Unit G is highly contorted and deformed. This deformed interval is $8.5 \mathrm{~m}$ thick in Hole U1395A and $7 \mathrm{~m}$ thick in Hole 
U1395B. The deformed unit comprises beds of different colors, which often exhibit strongly inclined contacts or mixed grain size.

\section{Unit H}

Depths: Hole U1395A = 113-121 mbsf, Hole $\mathrm{U} 1395 \mathrm{~B}=113-124 \mathrm{mbsf}$

Unit $\mathrm{H}$ is composed of a thick sequence of pumiceous volcaniclastic turbidites. In Hole U1395A, two thick deposits are identified between 113 and 121 mbsf. The deposits are 4 and $4.8 \mathrm{~m}$ thick. In Hole U1395B, two pumiceous turbidites are also present within the same depth range, and they are separated by $1.5 \mathrm{~m}$ of hemipelagite. All of these pumiceous deposits have the same characteristics. They are normally graded, and the matrix is dominantly composed of crystals, lava clasts, and minor pumice and carbonates. Pumice clasts measuring $1-2 \mathrm{~cm}$ in diameter occur at the base of the deposit and fine upward to a few millimeters in diameter at the top (Fig. F2). No amphibole is observed in these deposits, and clinopyroxene is not present in the upper part of the unit. The absence of amphibole and clinopyroxene indicates that these deposits originate from volcanoes in the central chain of Guadeloupe, as previously described for the fallout deposits in this unit, or from Montserrat.

\section{Unit I}

Depths: Hole U1395A = 121-223.3 mbsf (bottom of hole), Hole U1395B = 124-197 mbsf (bottom of hole)

Unit I extends from $121 \mathrm{mbsf}$ to the base of Hole U1395A and from 124 mbsf to the base of Hole U1395B. This unit represents the top of a succession of indurated muddy to silty hemipelagic sediment. This sediment is composed of semiconsolidated siltstones and mudstones. Most of them are heavily bioturbated.

\section{Paleontology and biostratigraphy}

Core catcher samples at Site U1395 contain calcareous nannofossils and planktonic and benthic foraminifers of varying abundances and at varying levels of preservation. Preservation deteriorates with depth, making the samples increasingly difficult to date. Both nannofossil and planktonic foraminiferal biostratigraphic data for Site U1395 suggest ages ranging from late Pleistocene to late Pliocene (Fig. F3). Biostratigraphic and paleomagnetic age determinations are in good general agreement (see "Paleomagnetism"). Sponge spicules, pteropods, and heteropods are abundant and generally well preserved in the upper samples. Otoliths are present throughout the core samples, and four different morphotypes are present. Ostracods are rare when present in Holes U1395A and U1395B.

\section{Calcareous nannofossils}

Of the 27 core catchers collected from Hole U1395A, 22 were analyzed for calcareous nannofossils, along with 18 of the 25 core catchers collected from Hole U1395B. The remaining samples were not analyzed because of the coarse nature of the material. Sample 340-U1395A-1H-CC yielded a characteristic Pleistocene assemblage with Geophyrocapsa oceanica, Rhabdosphaera clavigera, Gephyrocapsa muellerae, Helicosphaera kamptneri, Helicosphaera hyalina, and small $(<3 \mu \mathrm{m})$ forms that may be Emiliania huxleyi. However, because of the small size of this species, postcruise analysis using scanning electron microscopy will be beneficial. Pseudoemiliania lacunosa was not found in Sample 340-U1395A-1H-CC, dating the sample to $<0.289 \mathrm{Ma}$, Zone CN15 (Okada and Bukry, 1980).

Samples 340-U1395A-2H-6 to 11H-CC yielded a variety of gephyrocapsid species: P. lacunosa, Ceratolithus cristatus, H. hyalina, Calcidiscus leptoporus, R. clavigera, Calciosolenia murrayi, and Syracosphaera pulchra. The presence of $G$. oceanica indicates this sediment is within Subzone CN14b (Okada and Bukry, 1980) or the $P$. lacunosa Zone (Gartner, 1977). Large P. lacunosa specimens appear in Sample 340-U1395A-6H-CC, whereas $G$. oceanica starts diminishing in abundance in Sample 9H-CC. The preservation and abundance of these samples varies from good to poor and common to abundant, respectively, depending on the nature of the sediment in the core catcher. Generally, Samples 340-U1395A-2H-6 through 11H-CC show common to abundant species and good preservation. Samples 340-U1395A-12H-CC through 28X-CC show a lower Pleistocene assemblage with very small gephyrocapsids: Gephyrocapsa caribbeanica, P. lacunosa, C. leptoporus, and Crenalithus doronicoides. The latter was detected in Sample 340-U1395A-12H-CC, the first sample below the lowest occurrence of G. oceanica, indicating that this sediment is within Subzone CN13b (Okada and Bukry, 1980). Moreover, a high level of dominantly small Gephyrocapsa species was found, allowing placement within the small Gephyrocapsa Subzone (Gartner, 1977). The abundance of specimens within these samples ranges from barren (Samples 340-U1395A-17X-CC, 20X-CC, and 24XCC) to abundant (i.e., Samples 340-U1395A-23X-CC and 28X-CC). Preservation ranges from moderate to good within this zone.

A similar lower to upper Pleistocene assemblage was recovered in Hole U1395B. Sample 340-U1395B-1H-CC contained a variety of gephyrocapsids, such as $G$. oceanica and Gephyrocapsa parallela. A high number (common) of Helicosphaera were also detected $(H$. 
hyalina, H. kamptneri, and Helicosphaera carteri var. walichii). C. cristatus and Ceratolithus telesmus were found to be common with good preservation. With the absence of both P. lacunosa and small calcareous forms, such as E. huxleyi, Sample 340-U1395B-1H-CC was assigned to Zone CN14.

Samples 340-U1395B-3H-CC to 16X-CC contain a similar species assemblage to the equivalent depth in Hole U1395A (S. pulchra, G. oceanica, G. caribbeanica, $H$. hyalina, $R$. clavigera, C. leptoporus, C. cristatus, Pontosphaera discopora, Pontosphaera multipora, and $P$. lacunosa). Large specimens of $P$. lacunosa were abundant in Sample 340-U1395B-5H-CC and were increasingly prevalent in Sample $12 \mathrm{H}$-CC. Helicosphaera species, such as $H$. carteri, were abundant in Sample 340-U1395B-16X-CC. P. discopora and Pontosphaera japonica were common in Section 340U1395B-10H-6. The overall preservation of species in these samples is good with no signs of dissolution or etching. These samples were assigned to Subzone CN14a (Okada and Bukry, 1980) or the P. lacunosa Zone (Gartner, 1977). Samples 340-U1395B-17X-CC to 25X-CC yielded a characteristic lower Pleistocene assemblage with high levels (common to abundant) of small Gephyrocapsa, P. lacunosa, G. caribbeanica, and $C$. doronicoides. G. oceanica was not present in Samples 340-U1395B-17X-CC to 25X-CC. As a consequence, these samples were assigned to Zone $\mathrm{CN} 13 \mathrm{~b}$. The overall preservation of this zone is good; however, the abundance of species drastically decreases in Sample 340-U1395B-20X-CC because of the mixing of siliclastic fragments that were found within the sample. The lowermost Sample 340U1395B-25X-CC shows a high prevalence (common) of $H$. carteri.

\section{Planktonic foraminifers}

Of the 28 core catcher samples from Hole U1395A, 27 were analyzed for planktonic foraminifers, as well as all 25 core catcher samples from Hole U1395B. Planktonic foraminifers were generally found to be the dominant presence in the $>150 \mu \mathrm{m}$ size fraction, except in samples with high volcanic content or very poor preservation. In most samples, the assemblage of planktonic foraminifers is diverse but dominated by Globigerinoides ruber (white) and Globigerinoides sacculifer. The assemblage of planktonic foraminifers throughout the site is typical of subtropical waters, with other abundant species including Globigerina falconensis, Globigerinita glutinata, Globigerinoides elongatus, Globorotalia tumida, and Neogloboquadrina dutertrei (dextral). Three biozones were recorded: PT1b, PT1a, and PL6. The primary marker between Subzone PT1a and Zone PL6 (top occurrence [T] of Globigerinoides fistulosus) was not recorded because of the absence of G. fistulosus at this location. Zone PL6 was recognized, instead, based on the presence of Globorotalia exilis, a secondary datum within Zone PL6, in the lowest sample from Hole U1395A. Several secondary datums were recorded as well: Globorotalia flexuosa (0.07-0.40 Ma), Globigerinella calida (bottom occurrence $[\mathrm{B}]$ at $0.22 \mathrm{Ma})$, Globorotalia tosaensis (T $0.61 \mathrm{Ma}$ ), and G. exilis (T 2.1 Ma). The bottom of Globorotalia truncatulinoides was recorded, but because of the roughly concurrent bottom of the related species G. tosaensis, this datum should be disregarded as a true age designation. The base of this species is likely abnormal at this site because of either ecological or preservational differences. It should be noted that within the lower sections of this site, samples become highly indurated and preservation deteriorates, making biostratigraphic designations less certain. Although this uncertainty is an issue, these age designations are based on the rough agreement between nannofossils and planktonic foraminifers.

\section{Benthic foraminifers}

A total of 57 genera and 49 species were identified at Site U1395 in the $>150 \mu \mathrm{m}$ size fraction. Samples examined for benthic foraminifers in Holes U1395A and U1395B varied in diversity and preservation (generally moderate). Rotaliids have the highest diversity but are present in low abundances (1-10 specimens per sample) overall in Holes U1395A and U1395B. Cibicides and Cibicidoides are the dominant genera, and Cibicides wuellerstorfi is the most abundant species. Miliolids have very low diversity and are present in low abundances with the exception of Pyrgo murrhina, the dominant species. Similarly, agglutinated foraminifers are represented by the genera Sigmoilopsis, Bigenerina, and Vulvulina, and Karreriella bradyi is the dominant species. Benthic foraminiferal density is low in both Holes U1395A and U1395B, ranging between 1 and 88 foraminifers/g of sediment.

At this site, Siphonodosaria cooperensis, Vulvulina pennatula, Pleurostomella alternans, and Proxifrons inaequalis are present in relatively low abundances (1-10 specimens per sample) in Samples 340-U1395A-8HCC, $11 \mathrm{H}-\mathrm{CC}, 12 \mathrm{H}-\mathrm{CC}, 15 \mathrm{H}-\mathrm{CC}, 18 \mathrm{H}-\mathrm{CC}, 21 \mathrm{H}-\mathrm{CC}$, 22H-CC, and 26H-CC and 340-U1395B-20X-CC and 23X-CC. The last appearance datum (T) for this foraminiferal group is $0.58 \mathrm{Ma}$ (Hayward et al., 2006). Based on the presence of the genus Osangularia and species Uvigerina auberiana, Laticarinina pauperata, and Bulimina aculeata, a bathyal paleodepth is interpreted.

\section{Geochemistry}

Samples for headspace analyses were taken from 21 depths throughout Hole U1395A; none were taken 
from cores that consisted largely of coarse-grained material. With the exception of one sample (from Section 340-U1395A-9X-1) that had a methane concentration of $10.3 \mathrm{ppm}$, all other samples had levels between 2.1 and $3.1 \mathrm{ppm}$. No higher hydrocarbons were detected.

A total of 44 samples were taken for X-ray diffraction (XRD) and carbonate analysis. XRD results fall into three groups. Samples from pelagic sediment intervals predominantly contain calcite and high-Mg calcite \pm aragonite, together with minor volcanic phases (mostly plagioclase with lesser orthopyroxene and hornblende). The specific clay minerals present in each interval cannot generally be distinguished from the XRD patterns, but kaolinite, smectite, and glauconite were detected in several of the samples and generally become more abundant below $100 \mathrm{mbsf}$ (Fig. F4). Samples from volcanic-rich horizons contain dominant plagioclase and lesser amounts of orthopyroxene and hornblende, along with minor carbonate (Table T2).

$\mathrm{CaCO}_{3}$ weight percent is much higher in the largely pelagic section in the upper part of the hole than in the largely volcanic turbidites (i.e., values greater than $\sim 20 \% \mathrm{CaCO}_{3}$ have an average value of $\sim 55 \%$ ), but the presence of significant quantities $\mathrm{CaCO}_{3}$ in many of the volcanic turbidite sections indicates a significant biogenic component (Fig. F5A). $\mathrm{CaCO}_{3}$ content is higher $(\leq 88 \mathrm{wt} \%)$ in the semilithified sediments toward the base of the hole. Organic carbon concentrations in the pelagic sections are similar to those expected in this area (average $=\sim 1 \mathrm{wt} \%$ ) and are much lower in the turbidite sections (Fig. F5B). Organic carbon concentrations also increase toward the base of the hole $(\leq 1.5 \mathrm{wt} \%)$. The ratio of organic carbon to $\mathrm{CaCO}_{3}$, however, remains relatively constant in the hemipelagic intervals throughout the hole, suggesting that concentration increases simply reflect less dilution by volcanic material at depth (Table T2).

It is not possible to collect meaningful pore water data from permeable turbidite horizons, so all data are from zones dominated by hemipelagic sediments. Alkalinity values increased from $3.5 \mathrm{mM}$ in the uppermost two sections (340-U1395A-1H-3, $4.4 \mathrm{mbsf}$, and $2 \mathrm{H}-3,10.4 \mathrm{mbsf}$ ) to a maximum value of $7.5 \mathrm{mM}$ at 29.3 mbsf (Section $4 \mathrm{H}-3$ ), before decreasing to relatively constant values of $5.4 \mathrm{mM}$ from $72.7 \mathrm{mbsf}$ to the deepest sample at 195 mbsf (Fig. F6A). pH values are more variable than those observed in Hole U1394B, but no consistent pattern is observable in the data, suggesting they may contain some analytical artifacts. Ammonia concentrations increase from $0.01 \mathrm{mM}$ in the uppermost sample to $\sim 1.1 \mathrm{mM}$ at $72.7 \mathrm{mbsf}$ and only increase gradually to a value of $1.2 \mathrm{mM}$ at $185 \mathrm{mbsf}$ (Fig. F6B). Dissolved calcium concentrations are generally lower than bottom water values in samples from the uppermost 106 mbsf of Hole U1395A but show an increase to higher values approaching $15 \mathrm{mM}$ in the deepest samples (Fig. F6C). Although these samples come from semilithified sediment, the absence of concomitant alkalinity anomalies suggests that the high calcium concentrations are not simply related to squeezing artifacts. Interestingly, magnesium concentrations show a marked decrease at the same depth as the high calcium levels (Fig. F6D). These features are commonly seen in deep sediment pore water as a result of alteration of basaltic glass. Hence, it is possible that the covariation in calcium and magnesium concentrations in the deeper section of Hole U1395B may reflect a higher basaltic component in the volcanogenic material at this horizon. Sodium concentrations do not show a clear trend with depth, but potassium concentrations show a decrease with depth that is consistent with the reaction of pore water with volcanic material (Fig. F6E). Overall, $\Sigma$ S concentrations decrease slightly below the shallowest data point to near-constant values of $23-25 \mathrm{mM}$. Chloride concentrations show a slight increase below $30 \mathrm{mbsf}$ to a value of $\sim 570 \mathrm{mM}$, which is expected for pore water obtained from squeezing carbonate sediments (Table T3).

Three samples were taken for microbiological analysis after the piston core had been preloaded with a microsphere bag to assess potential surface contamination. A total of $20 \mathrm{~g}$ of sediment was taken for shore-based microbiological activity measurements and stored at $0^{\circ} \mathrm{C}$. A total of $4 \mathrm{~g}$ of sediment was taken for shore-based RNA analysis and stored at $-80^{\circ} \mathrm{C}$.

\section{Physical properties}

Holes U1395A and U1395B were cored to 121 and 124 mbsf, respectively, with the APC; low recovery below 124 mbsf constrains most of our data and interpretations to depths shallower than $120 \mathrm{mbsf}$. Depths generally refer to those of Hole U1395A. High magnetic susceptibility and low NGR identify volcaniclastic beds. GRA density distinguishes between volcaniclastic, bioclastic, and pumice-rich turbidites. Lower values of $S_{\mathrm{u}}$ obtained from the automated vane shear (AVS) and fall cone compared to results from the handheld penetrometer can be related to strength degradation after core splitting because the handheld penetrometer measures shear strength while the core is still in the core liner, immediately after the core arrives on deck. The sediment may not be fully depressurized from in situ conditions and therefore may have higher shear strength. The temperature gradient in the upper $44 \mathrm{~m}$ is $98.2^{\circ} \pm 8.8^{\circ} \mathrm{C} / \mathrm{km}$. The implied heat flow of $101 \mathrm{~mW} / \mathrm{m}^{2}$ is the highest measured at all Expedition 340 sites. 


\section{Stratigraphic correlation between Holes U1395A and U1395B}

We used both magnetic susceptibility and gamma ray attenuation (GRA) density data sets to correlate depths between Holes U1395A and U1395B (Fig. F7), with magnetic susceptibility providing the most robust correlation. Hole U1395A generally produced a cleaner, higher resolution magnetic susceptibility data set; we therefore used Hole U1395A as the reference and stretched Hole U1395B data as needed. Correlation is best in the uppermost $50 \mathrm{~m}$, where both holes had $\sim 100 \%$ recovery rates and clearly identifiable turbidite units (Fig. F7A). Between 50 and 115 mbsf, some discrepancy exists between the holes despite the use of the APC over this interval in both holes. We therefore attribute correlation discrepancies between 50 and 115 mbsf to slight differences in stratigraphy, as noted in the core description logs. Stratigraphic correlation between 60 and 80 mbsf and 90 and 110 mbsf shows the most significant discrepancies between the holes (Fig. F7B). Below 120 mbsf, we used the XCB to core, resulting in poor recovery. We were unable to make correlation ties below 115 mbsf. Although we did not use them for correlation, natural gamma radiation (NGR) data also show consistent trends between holes; it may be valuable in the future to use this to improve correlation at this site. The largest depth shift for the correlation picks is $3 \mathrm{~m}$, with most $<1 \mathrm{~m}$. All correlation pick depth shifts are shown in Table T4. Our correlation coefficient using these picks is 0.78 .

\section{Gamma ray attenuation density, magnetic susceptibility, and $P$-wave velocity}

Magnetic susceptibility (Fig. F8) clearly identifies volcaniclastic beds and turbidites with pronounced positive anomalies as high as $2800 \times 10^{-5}$ SI (e.g., 1320, 72-75, and 113-120 mbsf). Magnetic susceptibility typically increases downhole through turbidites. Ash layers have clear but smaller magnetic susceptibility signatures, with typical values of $700 \times 10^{-5}$ to $1500 \times$ $10^{-5} \mathrm{SI}$. Hemipelagic sediments have low and relatively constant magnetic susceptibility $\left(<350 \times 10^{-5} \mathrm{SI}\right)$. Magnetic susceptibility is relatively low in the bioclastic turbidite at 50-60 mbsf (mostly <700 $\times 10^{-5} \mathrm{SI}$ ).

NGR measurements (Fig. F8) are usually anticorrelated with magnetic susceptibility. NGR values are low for volcaniclastic beds (around 5 counts per second [cps]) and relatively high for hemipelagic sediment (around $10 \mathrm{cps}$ ).

GRA density values (Fig. F8) are as high as $2.0 \mathrm{~g} / \mathrm{cm}^{3}$ in turbidites that contain dense volcanic clasts but relatively low $\left(\sim 1.4 \mathrm{~g} / \mathrm{cm}^{3}\right.$; e.g., $\left.56-52 \mathrm{mbsf}\right)$ for bioclastic sediment. Whole-Round Multisensor Logger
(WRMSL) $P$-wave velocity (Fig. F8) generally increases with depth. Overall, volcaniclastic turbidites have higher velocities $(1750-1800 \mathrm{~m} / \mathrm{s})$ than hemipelagic sediment $(1500-1600 \mathrm{~m} / \mathrm{s})$.

\section{Thermal conductivity}

Thermal conductivity was measured on 36 sections. The mean thermal conductivity was $1.029 \mathrm{~W} /(\mathrm{m} \cdot \mathrm{K})$ with a standard deviation of $0.100 \mathrm{~W} /(\mathrm{m} \cdot \mathrm{K})$ and a standard error of the mean of $0.017 \mathrm{~W} /(\mathrm{m} \cdot \mathrm{K})$.

\section{Shear strength}

Undrained shear strength $\left(S_{\mathrm{u}}\right)$ was measured with three techniques (Fig. F8). The handheld penetrometer generally gives higher values than the AVS and the fall cone. Measurements of $S_{\mathrm{u}}$ obtained from the handheld penetrometer increase linearly downhole $(\sim 6 \mathrm{kPa} / \mathrm{m})$ to $40 \mathrm{mbsf}$ in Hole U1395B, whereas in Hole U1395A, $S_{\text {u }}$ decreases from 25 to 45 mbsf to $35 \mathrm{kPa}$. Below $45 \mathrm{mbsf}$, measured $S_{\mathrm{u}}$ ranges from 50 to $220 \mathrm{kPa}$ (the limit of the instrument).

The AVS shows a downhole linear trend from 15 to $86 \mathrm{kPa}$ in the $0-40$ mbsf interval $(\sim 2 \mathrm{kPa} / \mathrm{m})$. AVS measurements could not be performed in firm sediment and loose coarse-grained turbidities. AVS values are scattered below 60 mbsf. Fine-grained sediment on top of turbidite sequences has low shear strength (13-40 kPa between 40 and $100 \mathrm{mbsf}$ ).

Shear strength measured with the fall cone increases from 0 to $45 \mathrm{mbsf}$ (about $2 \mathrm{kPa} / \mathrm{m}$ ). No clear trend is observed from 45 to 65 mbsf because of the presence of positive incursions $(>400 \mathrm{kPa})$ and some relatively low shear strength values $(<50 \mathrm{kPa})$. Below $65 \mathrm{mbsf}$, $S_{\mathrm{u}}$ increases downhole (about $2 \mathrm{kPa} / \mathrm{m}$ ).

\section{$P$-wave velocity}

Discrete $P$-wave values measured on the $x$-axis (PW$\mathrm{X}$; Fig. F8) match $P$-wave logger (PWL) values, with velocities increasing with depth. Few discrete PW-X measurements exist for coarse, unconsolidated sediment (e.g., turbidites). Turbidites generally have higher $P$-wave velocities $(1750-1800 \mathrm{~m} / \mathrm{s})$ compared to hemipelagic sediment (1500-1600 m/s).

\section{Moisture and density}

We collected 53 moisture and density (MAD) samples (45 from Hole U1395A and 8 from Hole U1395B; Fig. F8). Porosity ranges from $\sim 48 \%$ to $67 \%$, showing a weak negative correlation with depth. Bulk density ranges from 1.55 to $1.95 \mathrm{~g} / \mathrm{cm}^{3}$ and increases with depth. Porosity of loose sands may be underestimated because of the draining of pore water during sampling or overestimated because of sediment reworking 
during core recovery. Alternatively, where core recovery, handling, or splitting processes reorganize sand grains, sandy sediment may become undercompacted and yield anomalously high porosities.

Grain density of hemipelagic samples range between 2.65 and $2.8 \mathrm{~g} / \mathrm{cm}^{3}$. Grain density of pumice-rich turbidites is lower, ranging between 2.45 and $2.55 \mathrm{~g} / \mathrm{cm}^{3}$. Dense volcaniclastic turbidites have grain density similar to hemipelagic sediment at Site U1395. Porosity decreases slightly with depth.

\section{Downhole temperature}

Temperature was measured with the advanced piston corer temperature tool (APCT-3) at the bottom of Cores 340-U1395B-3H, 4H, and 5H $(24.9,34.4$, and 43.9 mbsf, respectively). Downhole temperature was monitored for 683,697 , and 744 s, respectively. Temperature was calculated from these time series of temperature measurements using TP-Fit software (Heeseman et al., 2006; see APCT-3 user manual on the Cumulus/Techdoc database at iodp.tamu.edu/ tasapps/). We assumed a thermal conductivity $(k)$ of $1.0 \mathrm{~W} /(\mathrm{m} \cdot \mathrm{K})$ and $\rho \mathrm{C}=3.7 \times 10^{6} \mathrm{~J} / \mathrm{m}^{3} \mathrm{~K}$. To calculate uncertainty, we assumed $k$ ranges from 0.9 to $1.1 \mathrm{~W} /(\mathrm{m} \cdot \mathrm{K})$ and $\rho \mathrm{C}$ is between $3.2 \times 10^{6}$ and $4.0 \times$ $10^{6} \mathrm{~J} / \mathrm{m}^{3} \mathrm{~K}$. At the base of Cores $340-\mathrm{U} 1395 \mathrm{~B}-3 \mathrm{H}, 4 \mathrm{H}$, and $5 \mathrm{H}$, we obtained estimated equilibrium temperatures of $7.11^{\circ} \pm 0.03^{\circ} \mathrm{C}, 8.44^{\circ} \pm 0.02^{\circ} \mathrm{C}$, and $9.48^{\circ} \pm$ $0.02^{\circ} \mathrm{C}$, respectively. These reported uncertainties are similar to the error on the best-fit solution and the probe's measurement accuracy.

Temperature of ocean water at the seafloor was $5.15^{\circ} \pm$ $0.04^{\circ} \mathrm{C}$. A best-fit linear relationship between depth and our four temperature measurements gives a temperature gradient of $98.2^{\circ} \pm 8.8^{\circ} \mathrm{C} / \mathrm{km}$ (Fig. F9). Using the measured thermal conductivity, the implied heat flow, if conductive, is $101 \pm 9 \mathrm{~mW} / \mathrm{m}^{2}$. No correction for sedimentation and bathymetry are needed. The high permeability of the coarse turbidites may also disturb subsurface temperatures by advection; however, there is no statistically significant deviation of the measurements from a straight (conductive heat transfer) line, at least in the upper $44 \mathrm{~m}$ where we have data (Manga et al., 2012).

\section{Paleomagnetism}

Cores 340-U1395A-2H through 9H and 340-U1395B$2 \mathrm{H}$ through $10 \mathrm{H}$ were recovered with the APC using nonmagnetic core barrels. All other APC cores were recovered using standard steel barrels. The FlexIt orientation tool was used on all APC cores recovered with nonmagnetic barrels from Hole U1395A; thus, between 3.1 and 72.4 mbsf in U1395A, declination can be corrected to true north. Where FlexIt tool data were not available, declination was guided by the discrete inclination data (see "Paleomagnetism" in the "Methods" chapter [Expedition 340 Scientists, 2013a]). Expected inclination for the site is $30.6^{\circ}$ during normal polarity and $-30.6^{\circ}$ during reversed polarity, assuming a geocentric axial dipole (GAD). The archive halves of cores from Holes U1395A and U1395B were measured on the three-axis superconducting rock magnetometer (SRM) at $2.5 \mathrm{~cm}$ intervals (Table T5). NRM was measured before $\left(\mathrm{NRM}_{0}\right)$ and after stepwise alternating field (AF) demagnetization at $10 \mathrm{mT}\left(\mathrm{NRM}_{10}\right)$ and $20 \mathrm{mT}\left(\mathrm{NRM}_{20}\right)$. In cores that were visibly disturbed, only $\mathrm{NRM}_{0}$ and $\mathrm{NRM}_{20}$ were measured to maintain workflow through the laboratory. Twenty-nine discrete samples were collected from the center of the working half of the core to compare to the SRM data (see "Paleomagnetism" in the "Methods" chapter [Expedition 340 Scientists, 2013a]).

Sediment recovered from Site U1395 is heterogeneous in composition and varies between layers of hemipelagic sedimentation and deposits related to volcanic activity, particularly volcanic turbidites (see "Lithostratigraphy"). Using the detailed core description logs, we only interpret directional data measured on hemipelagic layers, as these appear the least disturbed and are the most likely to hold information about the behavior of the paleogeomagnetic field.

\section{Results}

$\mathrm{NRM}_{0}$ (red) and $\mathrm{NRM}_{20}$ (blue) intensities are shown for Holes U1395A and U1395B in Figures F10 and F11. $\mathrm{NRM}_{0}$ intensity is relatively high, $>1 \mathrm{~A} / \mathrm{m}$, and exhibits structure similar to magnetic susceptibility (see "Physical properties"), suggesting $\mathrm{NRM}_{0}$ is related to the concentration of ferrimagnetic iron oxides present within volcaniclastic material. The $\mathrm{NRM}_{0}$ intensity of sediment recovered with steel barrels is an order of magnitude higher than those recovered with nonmagnetic barrels, a trend not mirrored in the magnetic susceptibility profile (Fig. F12; see "Physical properties"). These cores all show steep positive inclination contradicting the corresponding discrete samples which record both positive and negative inclination GAD-like values (Figs. F10, F11). Similar to sediment in Site U1394, we interpret this as a strong magnetic overprint caused by remagnetization of the sediment within the standard steel barrels, which is not removed by AF demagnetization in a field of $20 \mathrm{mT}$ (e.g., Fuller et al., 2006). With the use of nonmagnetic core barrels, these effects are mitigated, and there is excellent agreement in both inclination and declination between the SRM data and the discrete data (Figs. F10, F11). These data 
cluster and plot around the expected GAD inclination for the site. Declination data agree well with the use of both standard and nonmagnetic barrels, suggesting the radial overprint is not as severe as the vertical overprint and potentially more useful for interpretation of polarity in sediment recovered using steel barrels.

In Hole U1395A, changes in both inclination and declination indicate the depth of the Brunhes/Matuyama (B/M) polarity reversal boundary at $\sim 66$ mbsf. A turbidite masks the $\mathrm{B} / \mathrm{M}$ inclination transition in Hole $\mathrm{U} 1395 \mathrm{~B}$; the last negative inclination values are $71.9 \mathrm{mbsf}$, and the first recorded positive inclination values are at 67.7 mbsf. When recovered using steel barrels, discrete inclination points are used to guide the polarity of the SRM declination (see "Paleomagnetism" in the "Methods" chapter [Expedition 340 Scientists, 2013a]). These data show the transition from the Jaramillo (normal) Chron into the Matuyama (reversed) Chron at $~ 90$ mbsf in Hole U1395A and 89.5 mbsf in Hole U1395B. A sequence of unconsolidated tephras and turbidites, severely faulted and altered sediment, and poor recovery below 100 mbsf (see "Core descriptions") makes further interpretation of polarity difficult. The lower Jaramillo transition may be recorded by three discrete inclination points around 101 mbsf in Hole U1395A and a single discreet datapoint at 116 mbsf in Hole U1395B; however, further analysis is required for confirmation.

Using the magnetic susceptibility correlation between both holes (see "Physical properties"), we can transfer depth in Hole U1395B to depth in Hole U1395A and produce an aggregated inclination record for the site (Fig. F12). Excellent agreement between the nonmagnetic barrel SRM data and all discrete data gives further confidence in the paleomagnetic interpretations. Using the geomagnetic polarity timescale (GPTS) of Cande and Kent (1995), the age of the B/M boundary is defined at $0.78 \mathrm{Ma}$ and the Upper Jaramillo at $0.99 \mathrm{Ma}$. Paleomagnetic data agree well with biostratigraphic ages for the site (see "Paleontology and biostratigraphy"; Fig. F13). Sedimentation rates for the site calculated from the paleomagnetic data are therefore $\sim 8 \mathrm{~cm} / \mathrm{k} . \mathrm{y}$. during the Brunhes Chron with slightly higher rates at the end of the Matuyama Chron of $\sim 11 \mathrm{~cm} / \mathrm{k} . \mathrm{y}$. A longer term average rate from the end of the Jaramillo gives average sedimentation of $9 \mathrm{~cm} / \mathrm{k} . \mathrm{y}$. for the whole period.

\section{Downhole logging}

Two tool strings were used to $\log$ a $120 \mathrm{~m}$ section of Hole U1395B over a period of $\sim 12 \mathrm{~h}$ (Fig. F14). The borehole remained in good condition while downhole logging measurements-including gamma ray, density, electrical resistivity and images, and velocity-were obtained.

\section{Operations}

Downhole logging operations commenced on the morning of 16 March 2012 after sweeping and displacing Hole U1395B with heavy logging mud and pulling the pipe to a bit depth of 82.3 mbsf. The first tool string deployed was the triple combo-Magnetic Susceptibility Sonde (MSS) tool string, which included the Hostile Environment Natural Gamma Ray Sonde (HNGS), Hostile Environment Litho-Density Sonde (HLDS), High-Resolution Laterolog Array (HRLA), and MSS (see "Downhole logging" section in the "Methods" chapter [Expedition 340 Scientists, 2013a] for tool string details). Having experienced good hole conditions throughout the coring of both Holes U1395A and U1395B, the ${ }^{137}$ Cs source was deployed with the HLDS sonde, allowing for acquisition of a density measurement. The tool string was lowered to a total depth of $204.8 \mathrm{mbsf}$, from where an initial uplog at $900 \mathrm{ft} / \mathrm{h}$ was completed to $115 \mathrm{mbsf}$. This was followed by a repeat pass from total depth back through the bit at the same speed. The tools were rigged down by $1100 \mathrm{~h}$. Unfortunately the MSS malfunctioned during this run despite tool diagnostics being normal, so resulting susceptibility data are unusable.

The FMS-sonic tool string (see Fig. F11 in the "Methods" chapter [Expedition 340 Scientists, 2013a]) was the second tool string to be run in this hole, for the purpose of acquiring acoustic velocity and electrical image data. Two uplogs were completed through the open hole section at a speed of $1800 \mathrm{ft} / \mathrm{h}$, after which the tool string was pulled to the rig floor. Logging operations were completed at $1615 \mathrm{~h}$.

\section{Data processing and quality assessment}

A depth shift to seafloor was applied to all logs, with the seafloor identified from the gamma ray data sets. A subtle inflection in the gamma ray (from the Enhanced Digital Telemetry Cartridge [EDTC] and HNGS) associated with the seafloor was observed at 1197.7 mbsl. Following the shift to seafloor, curves were depth-matched using the gamma ray from the HNGS recorded during the main pass of the triple combo as the reference curve. Logs from the other tool string passes (triple combo and FMS-sonic) were matched to this log through identification of common features through the logged section.

Caliper data from both tool strings (from the HLDS and FMS) indicate that Hole U1395B is relatively in gauge, with a similar profile to Hole U1394B. Hole 
diameter ranges from $\sim 11$ inches at the base of the hole to a slightly flared region $(\leq 17$ inches in diameter) just below the bit (Figs. F15, F16). This range in diameter and the fact the borehole profile is relatively smooth means that borehole conditions are reasonably favorable for the acquisition of good downhole measurements.

The quality of the logs can also be assessed by comparison with measurements made on cores from the same hole. Figure F15 shows a comparison of the gamma ray and density logs with the natural gamma ray track core logging data and with the moisture and density (MAD) measurements made on cores. The different sets of measurements display reasonably good agreement where core recovery was excellent. Between 119 and 125 mbsf, logging data show higher values for gamma ray and density than the respective core data, and below 125 mbsf, there is very little core data to compare because of incomplete recovery. Because of the in situ nature of the gamma ray and density logs, their values should be equal or slightly higher than the same measurements made on the recovered core.

The repeatability of all of the logging measurements is very good between the first and second passes for both tool strings (Fig. F17). In addition, gamma ray measurements from both tool strings agree well (Fig. F16).

HRLA resistivity data are of generally very good quality, with logs from the different depths of investigation agreeing very well (Fig. F15). In the interval from $\sim 99$ to 112 mbsf, the log response indicates a high-frequency noise overprint in the data. This may be a function of the tool dynamics and the proximity to the pipe. The overall trend through this interval is reliable; however, the finer detail should be ignored.

Dipole Shear Sonic Imager (DSI) modes for this hole were the same as for Hole U1394B, with the monopole and upper dipole set to standard frequency and the lower dipole set to low frequency. Given the nature of the recovered cores, it was hoped this would optimize data quality. Compressional wave velocity $\left(V_{\mathrm{P}}\right)$ logs are of good quality, and values are highly coherent (Fig. F16). However, shear wave velocity $\left(V_{S}\right)$ data for this hole will need some postcruise processing, particularly in the interval from 85 to $128 \mathrm{mbsf}$. $V_{\mathrm{S}}$ values between $\sim 400$ and $900 \mathrm{~m} / \mathrm{s}$ in this interval are very coherent and can be trusted, but $V_{\mathrm{S}}$ values that exceed $900 \mathrm{~m} / \mathrm{s}$ are anomalous and should not be interpreted.

FMS image quality relies on good contact between the tool's pads and the borehole walls. This should have been achieved in this in-gauge hole, and the resulting images indicate that this was generally the case. Unfortunately, toward the top of the open hole section the cable tension on the wireline increased and the calipers were closed through a $5 \mathrm{~m}$ interval. As such, coverage of the $120 \mathrm{~m}$ section is not as extensive as planned.

\section{Logging stratigraphy}

Three logging units have been identified on the basis of characteristic features and trends in the downhole measurements data set. These units are identified in Figures F15, F16, and F18, and a description of their geophysical properties follows.

\section{Logging Unit 1}

Logging Unit 1, from 85 to $112 \mathrm{mbsf}$, is characterized by relatively consistent downhole profiles in density, resistivity, and $V_{\mathrm{p}}$, all of which exhibit low-amplitude variability. Gamma ray data over this interval fluctuate around a mean value of 20 gAPI. Density appears to have a step increase at $\sim 92 \mathrm{mbsf}$, but this is most likely a response to the closing of the eccentralizing caliper at this depth at the end of the logging run. Discarding density data from 85 to 92 mbsf gives a mean value of $1.8 \mathrm{~g} / \mathrm{cm}^{3}$ in this logging unit. Resistivity in the upper part of this unit has an average value of $1.32 \Omega \mathrm{m}$. At $\sim 100 \mathrm{mbsf}$ there is a subtle shift in the profile to lower resistivity values (mean = $1.26 \Omega \mathrm{m}) . \quad V_{\mathrm{P}}$ demonstrates a slight increase with depth from $\sim 1550 \mathrm{~m} / \mathrm{s}$ at the top of the unit to $\sim 1620 \mathrm{~m} / \mathrm{s}$ at the base.

\section{Logging Unit 2}

Logging Unit 2 is distinguished from overlying logging Unit 1 at 112 mbsf on the basis of a sharp decrease in gamma ray, increases in density and resistivity, and a broad change in the character of the logging profiles. Gamma ray, density, resistivity, and $V_{\mathrm{P}}$ all show high-amplitude variations throughout this unit, relative to Unit 1. Logging Unit 2 is further divided based on the relative responses of the different geophysical properties.

\section{Logging Subunit $2 A$}

Gamma ray in logging Subunit 2A (112-137 mbsf) generally increases with depth and has a mean gamma ray value of 19 gAPI. The profile is punctuated by a series of intervals of lower gamma ray values (Fig. F15) that coincide with increases in density, resistivity, and $V_{p}$. These features may correspond to the turbidites observed in cores recovered from Holes U1395A and U1395B (see "Lithostratigraphy"). Resistivity values subtly increase with depth (average $=$ $1.5 \Omega \mathrm{m})$, a trend that is echoed by the density values $\left(\right.$ mean $\left.=1.9 \mathrm{~g} / \mathrm{cm}^{3}\right)$. Both of these profiles are easily 
discerned from the overlying unit by some significant positive departures (notably at $\sim 113$ and $\sim 119$ mbsf) from these subtle trends.

\section{Logging Subunit 2B}

Logging Subunit 2B is distinguished from Subunit 2A for two main reasons. First, the profiles do not exhibit a net change with depth, but rather vary around a constant value. Second, the subunit is characterized by a series of gamma ray highs that do not coincide with changes in the other data sets in a consistent way. Broadly, there are two classes of gamma ray highs identified: (1) those that correspond to increases in density, resistivity and $V_{\mathrm{p}}$ (for example at $\sim 140,145$, and 162 mbsf) and (2) those that coincide with decreases in density and resistivity and minor increases in $V_{\mathrm{P}}$ (for example at 149 and $161 \mathrm{mbsf}$ ). Average values of gamma ray and $V_{\mathrm{P}}$ are somewhat elevated with respect to the overlying Subunit 2A (20 gAPI and $\sim 1800 \mathrm{~m} / \mathrm{s}$, respectively), whereas mean density and resistivity values are slightly lower $\left(1.82 \mathrm{~g} / \mathrm{cm}^{3}\right.$ and $1.4 \Omega \mathrm{m}$, respectively).

\section{Logging Unit 3}

Logging Unit 3 (163-202 mbsf) is characterized by a return to lower frequency variations in all downhole logging measurements, similar to what is seen in logging Unit 1. Gamma ray values range from $\sim 17$ to 27 gAPI with an average similar to the overlying units (20 gAPI). Density exhibits very low amplitude variation around a mean value of $1.73 \mathrm{~g} / \mathrm{cm}^{3}$. Resistivity is relatively invariant with depth in this logging unit, with a mean value of $1.2 \Omega \mathrm{m}$. Because the HRLA tool is located lower in the tool string, resistivity measurements extend deeper than the other data types. A highly resistive layer centered on $188 \mathrm{mbsf}$ may coincide with the recovery of a partial core (340-U1395B-24H) containing lithified material. $V_{\mathrm{P}}$ data in logging Unit 3 show a subtle increase with depth and are similar in character to that of logging Unit 1 . However, the average value $(\sim 1800 \mathrm{~m} / \mathrm{s})$ is elevated in the lower unit, which is consistent with what might be expected with a classical compaction trend.

\section{Formation MicroScanner images}

Figure F19 gives some examples of FMS images acquired from Hole U1395B. Across the logged section a range of textures and features can be identified, including some dipping surfaces and some highly resistive layers. FMS image data are only available for most of logging Units 2 and 3, from 112 to 202 mbsf. In the statically processed images (Figs. F16, F19), the range of resistivities encountered in logging Unit 2 is greater than that in logging Unit 3. The top half of Subunit 2A is characterized by sharply contrasting boundaries with some very resistive and also very conductive layers. In contrast, the lower half of the unit exhibits more subtle variations toward the more resistive end of the spectrum. Subunit $2 \mathrm{~B}$ is marked by a shift back to more definite changes across boundaries and is punctuated by some very resistive layers, most notably at $150-153$ mbsf.

Logging Unit 3 is dominated by material with moderate to low resistivity. Boundaries between different layers range from gradational to sharp, in terms of resistivity.

Integrating the textures and structures seen on the FMS images with images of the core is difficult because of poor recovery through much of the logged section. However, using them in combination with the rest of the Hole U1395B data set may help to elucidate the nature of some of the missing core.

\section{References}

Cande, S.C., and Kent, D.V., 1995. Revised calibration of the geomagnetic polarity timescale for the Late Cretaceous and Cenozoic. J. Geophys. Res., [Solid Earth], 100(B4):6093-6095. doi:10.1029/94JB03098

Expedition 340 Scientists, 2013a. Methods. In Le Friant, A., Ishizuka, O., Stroncik, N.A., and the Expedition 340 Scientists, Proc. IODP, 340: Tokyo (Integrated Ocean Drilling Program Management International, Inc.). doi:10.2204/iodp.proc.340.102.2013

Expedition 340 Scientists, 2013b. Site U1394. In Le Friant, A., Ishizuka, O., Stroncik, N.A., and the Expedition 340 Scientists, Proc. IODP, 340: Tokyo (Integrated Ocean Drilling Program Management International, Inc.). doi:10.2204/iodp.proc.340.104.2013

Fuller, M., Molina-Garza, R., Touchard, Y., and Kidane, T., 2006. Paleomagnetic records from carbonate legs in the Southern Oceans and attendant drilling and coring related effects. In Sager, W.W., Acton, G.D., Clement, B.M., and Fuller, M. (Eds.), ODP Contributions to Paleomagnetism. Phys. Earth Planet. Int., 156(3-4):242-260. doi:10.1016/j.pepi.2005.08.007

Garcia, M.O., Sherman, S.B., Moore, G.F., Goll, R., PopovaGoll, I., Natland, J.H., and Acton, G., 2006. Frequent landslides from Koolau volcano: results from ODP Hole 1223A. J. Volcanol. Geotherm. Res., 151(1-3):251-268. doi:10.1016/j.jvolgeores.2005.07.035

Gartner, S., 1977. Calcareous nannofossil biostratigraphy and revised zonation of the Pleistocene. Mar. Micropaleontol., 2:1-25. doi:10.1016/0377-8398(77)90002-0

Hayward, B.W., Kawagata, S., Grenfell, H.R., Droxler, A.W., and Shearer, M., 2006. Mid-Pleistocene extinction of bathyal benthic foraminifera in the Caribbean Sea. Micropaleontology, 52(3):245-265. doi:10.2113/gsmicropal.52.3.245

Heesemann, M., Villinger, H., Fisher, A.T., Tréhu, A.M., and White, S., 2006. Data report: testing and deployment of 
the new APCT-3 tool to determine in situ temperatures while piston coring. In Riedel, M., Collett, T.S., Malone, M.J., and the Expedition 311 Scientists. Proc. IODP, 311: Washington, DC (Integrated Ocean Drilling Program Management International, Inc.). doi:10.2204/ iodp.proc.311.108.2006

Hunt, J.E., Wynn, R.B., Masson, D.G., Talling, P.J., and Teagle., D.A.H., 2011. Sedimentological and geochemical evidence for multistage failure of volcanic island landslides: a case study from Icod landslide on north Tenerife, Canary Islands. Geochem., Geophys., Geosyst., 12:Q12007. doi:10.1029/2011GC003740

Manga, M., Hornbach, M.J., Le Friant, A., Ishizuka, O., Stroncik, N., Adachi, T., Aljahdali, M., Boudon, G., Breitkreuz, C., Fraass, A., Fujinawa, A., Hatfield, R., Jutzeler, M., Kataoka, K., Lafuerza, S., Maeno, F., Martinez-Colon, M., McCanta, M., Morgan, S., Palmer, M.R., Saito, T., Slagle, A., Stinton, A.J., Subramanyam, K.S.V., Tamura, Y., Talling, P.J., Villemant, B., Wall-Palmer, D., and Wang, F., 2012. Heat flow in the Lesser Antilles island arc and adjacent backarc Grenada basin. Geochem., Geophys., Geosyst., 13:Q08007. doi:10.1029/2012GC004260
Okada, H., and Bukry, D., 1980. Supplementary modification and introduction of code numbers to the low-latitude coccolith biostratigraphic zonation (Bukry, 1973; 1975). Mar. Micropaleontol., 5:321-325. doi:10.1016/ 0377-8398(80)90016-X

Trofimovs, J., Amy, L., Boudon, G., Deplus, C., Doyle, E., Fournier, N., Hart, M.B., Komorowski, J.C., Le Friant, A., Lock, E.J., Pudsey, C., Ryan, G., Sparks, R.S.J., and Talling, P.J., 2006. Submarine pyroclastic deposits formed at the Soufrière Hills Volcano, Montserrat (19952003): what happens when pyroclastic flows enter the ocean? Geology, 34(7):549-552. doi:10.1130/G22424.1

Wynn, R.B., and Masson, D.G., 2003. Canary Islands landslides and tsunami generation: can we use turbidite deposits to interpret landslide processes? In Locat, J., and Mienert, J. (Eds.), Submarine Mass Movements and Their Consequences. Adv. Nat. Technol. Hazards Res., 19(2):325-332. doi:10.1007/978-94-010-0093-2_36

Publication: 17 August 2013 MS 340-105 
Figure F1. Site U1395 maps. A. Shaded image of topography-bathymetry, chaotic deposits (interpreted as debris avalanche deposits), and drill sites, Expedition 340. DAD = debris avalanche deposit. (Continued on next page.)

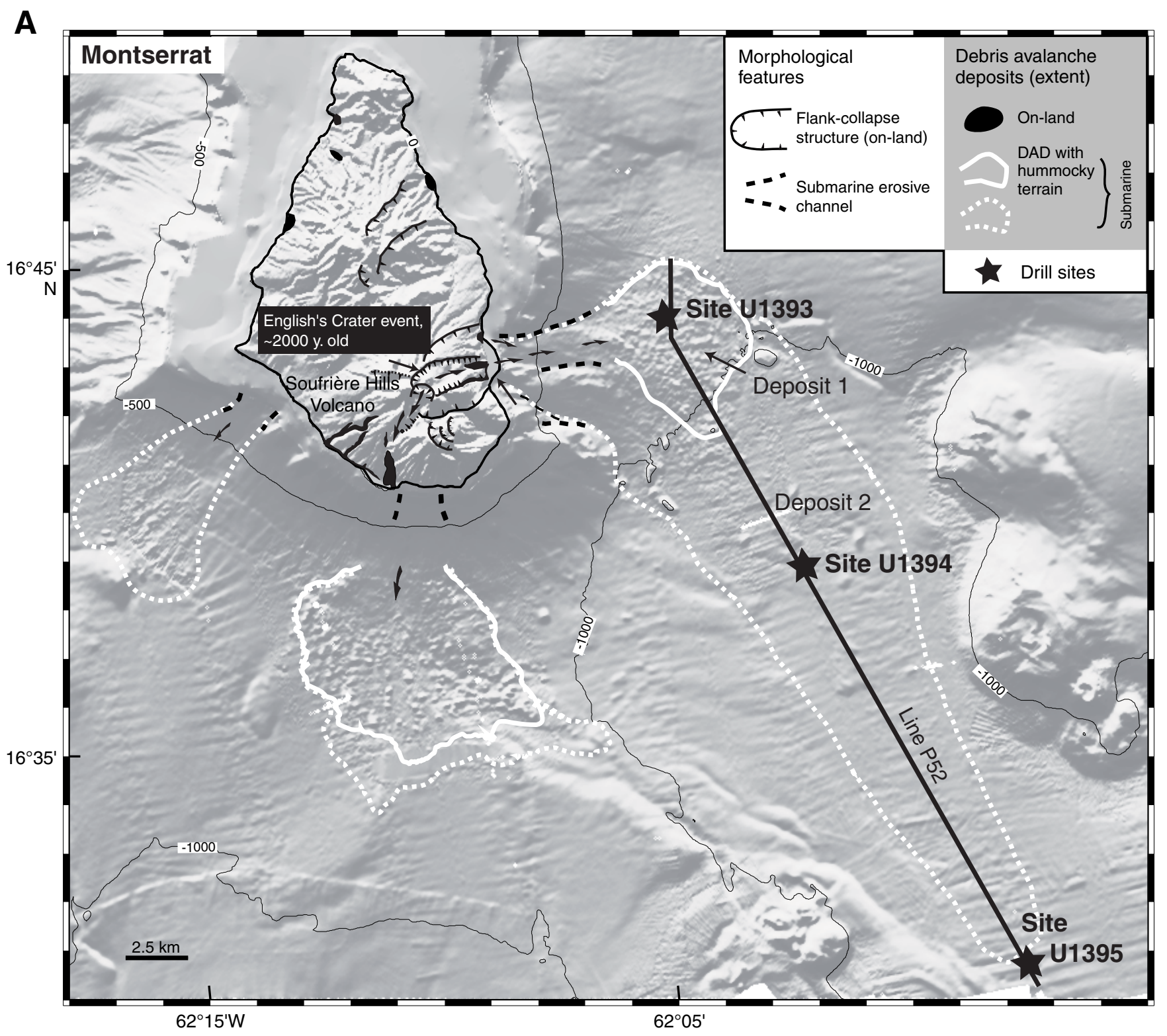


Figure F1 (continued). B. Location of seismic reflection lines, Site U1395.

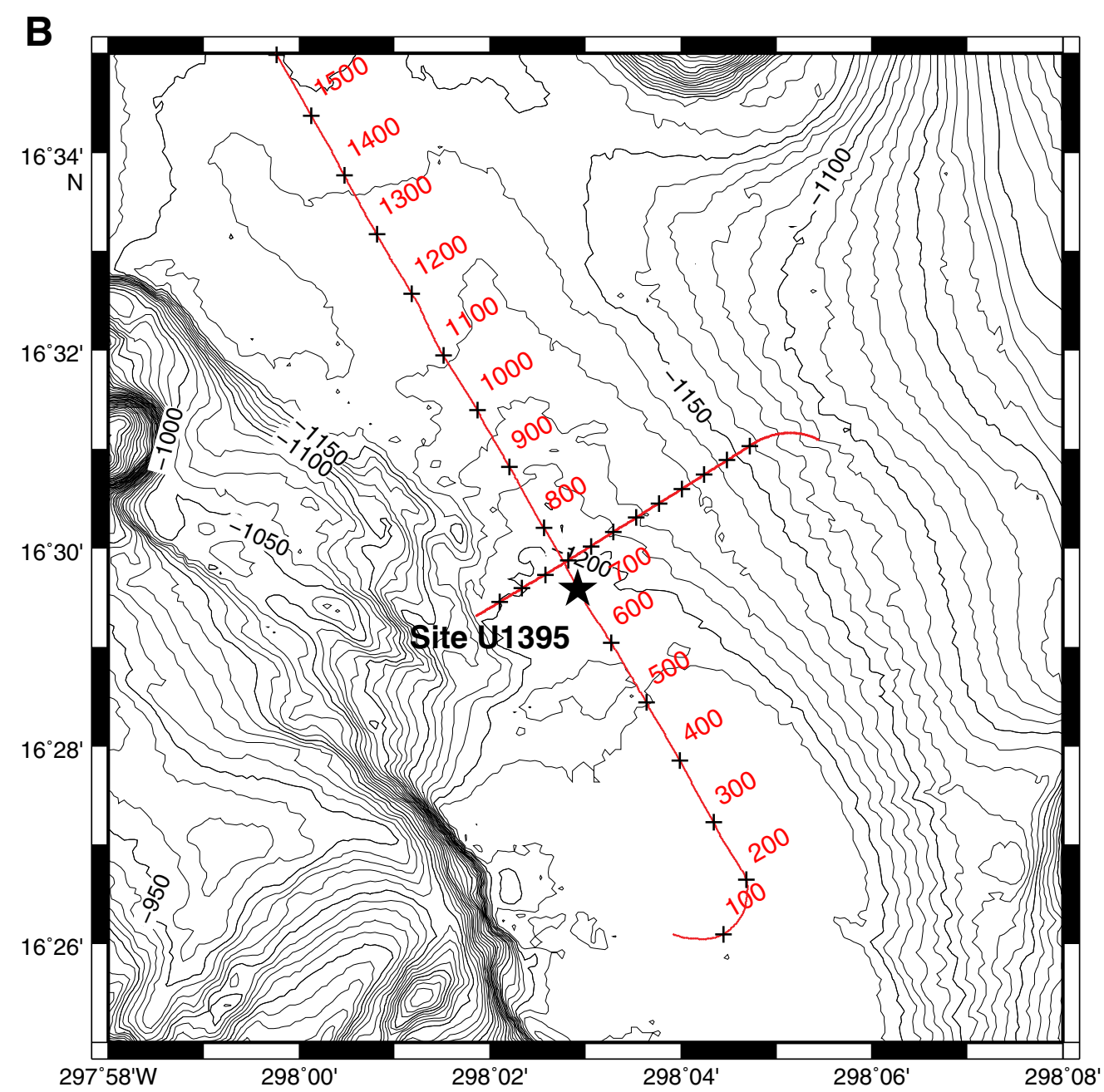


Figure F2. Pumice-rich bed from Hole U1395A. Base of the $190 \mathrm{~cm}$ section (right) contains pumice clasts as large as pebble sized in a clast-supported matrix. The bed fines upward toward the left, grading into medium sand-sized pumice clasts. Several large mud clasts are present in the top of the section.
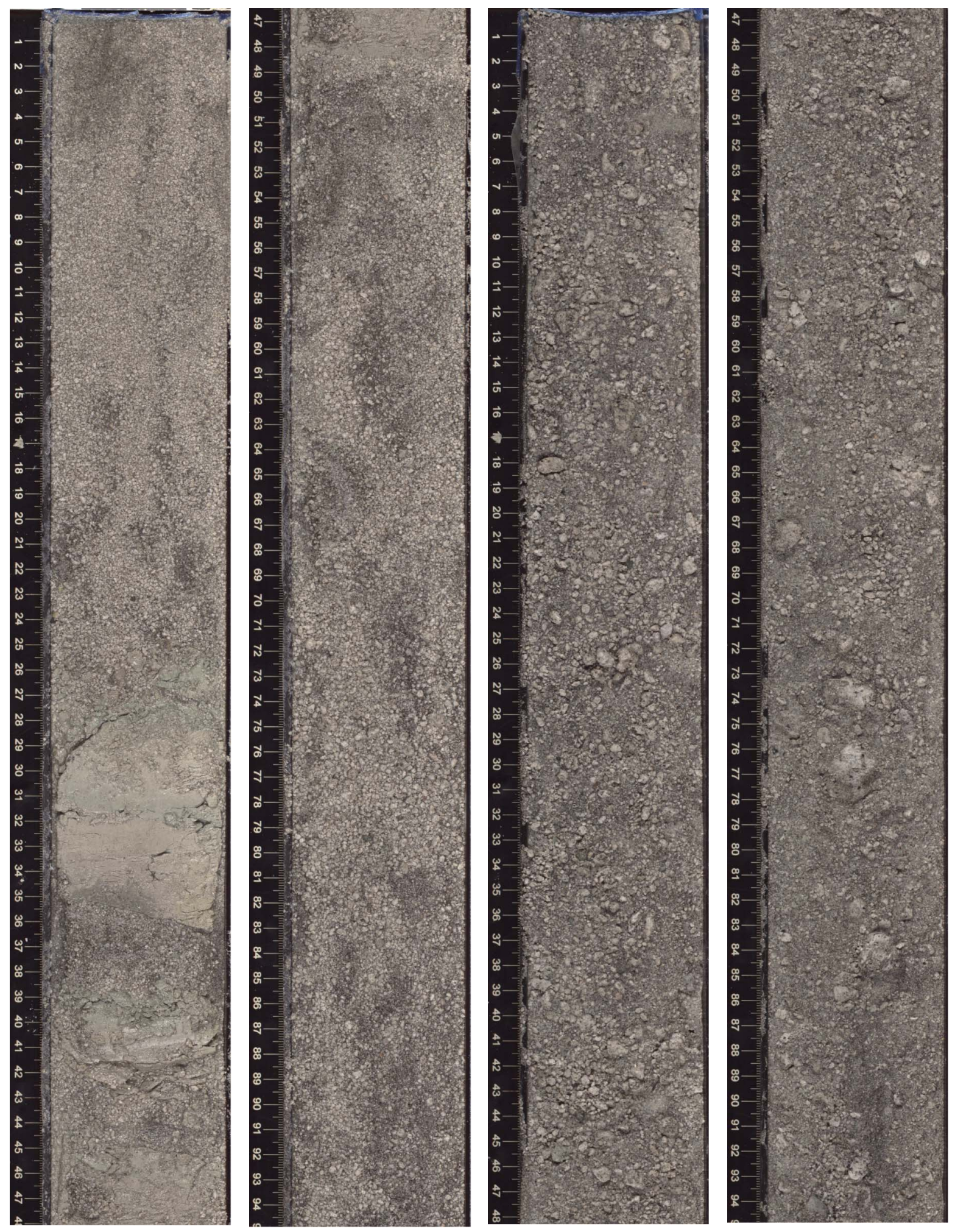
Figure F3. Integrated nannofossil and planktonic foraminiferal biozonation, Site U1395.

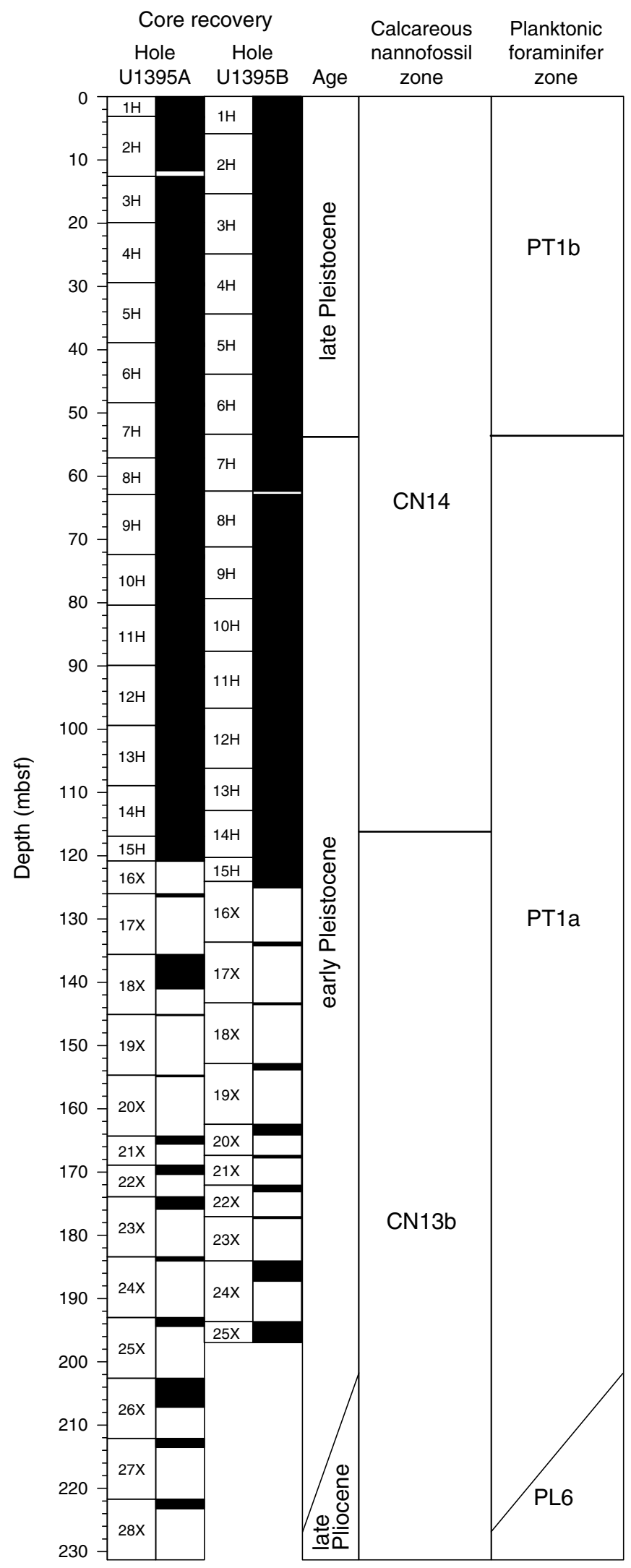




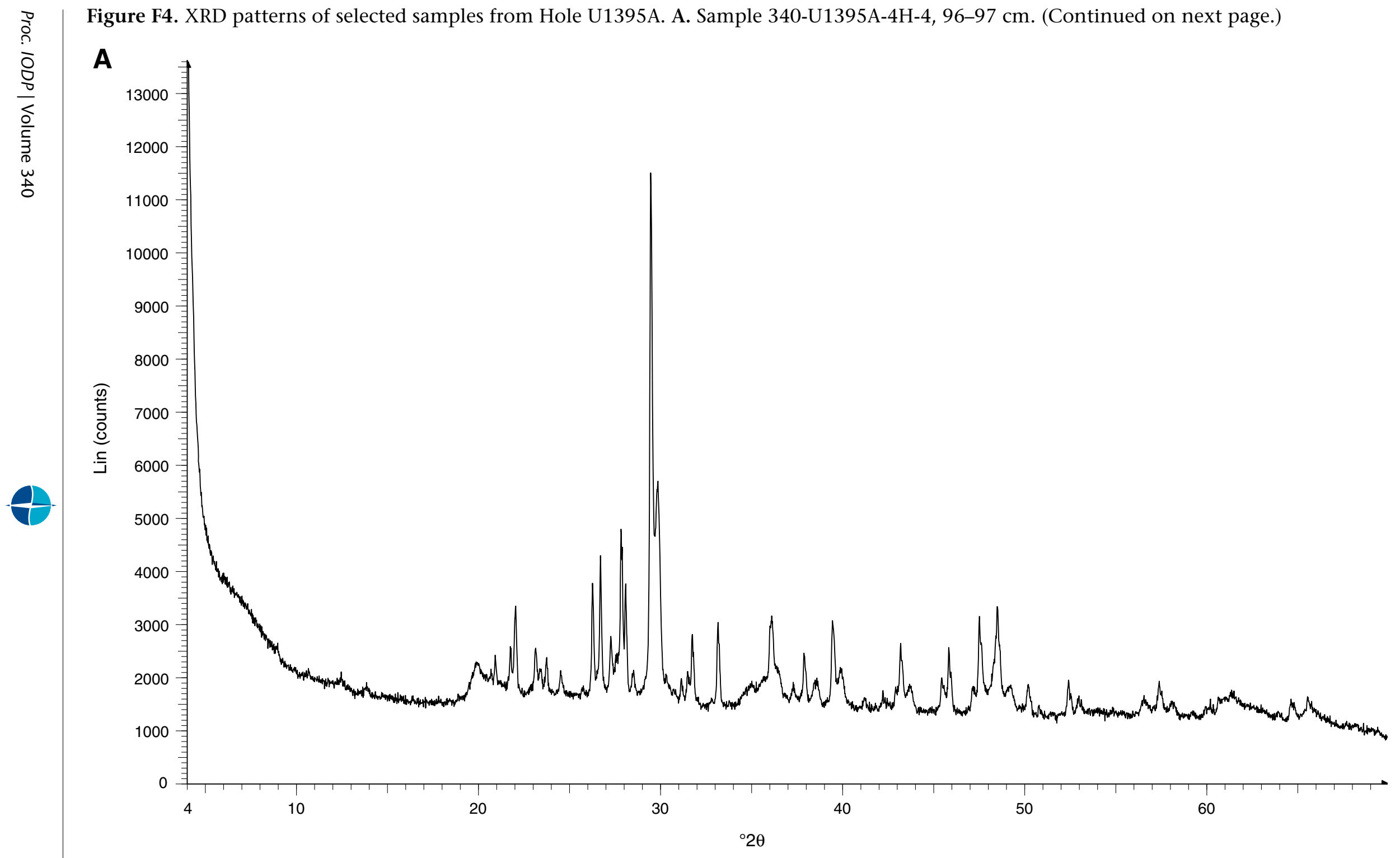




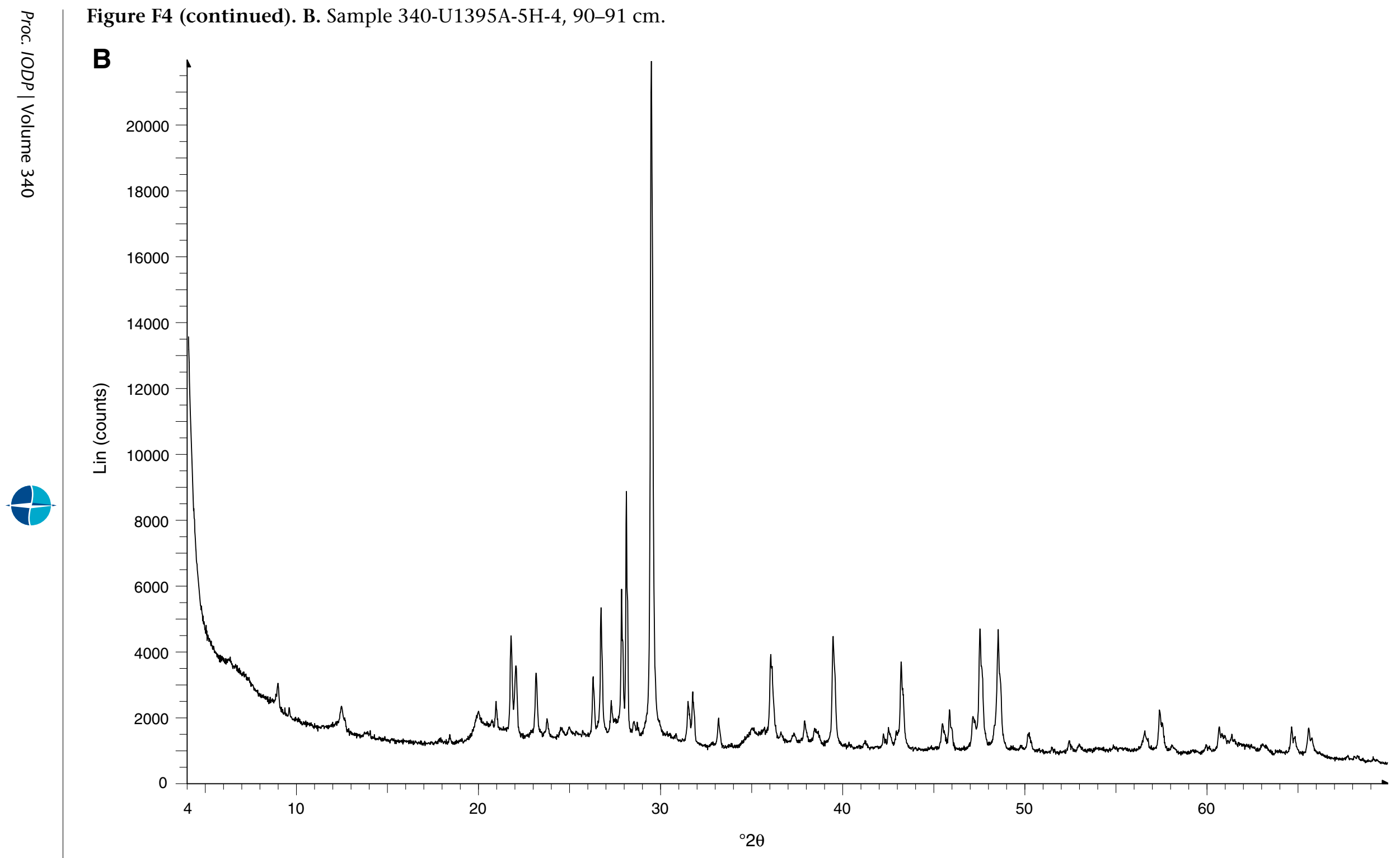


Figure F5. Solid-phase geochemical depth profiles, Site U1395. A. CaCO . B. Organic carbon.
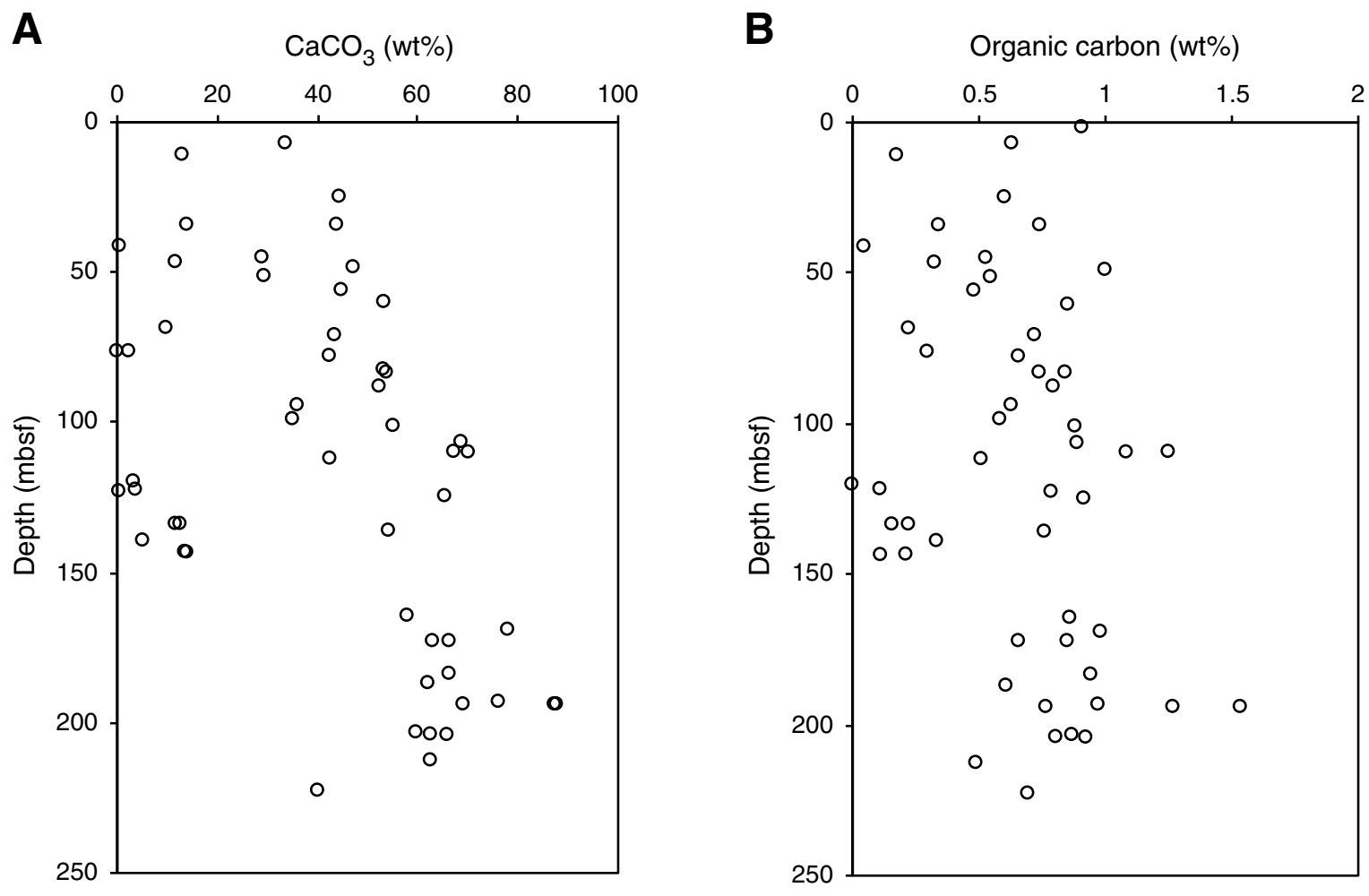


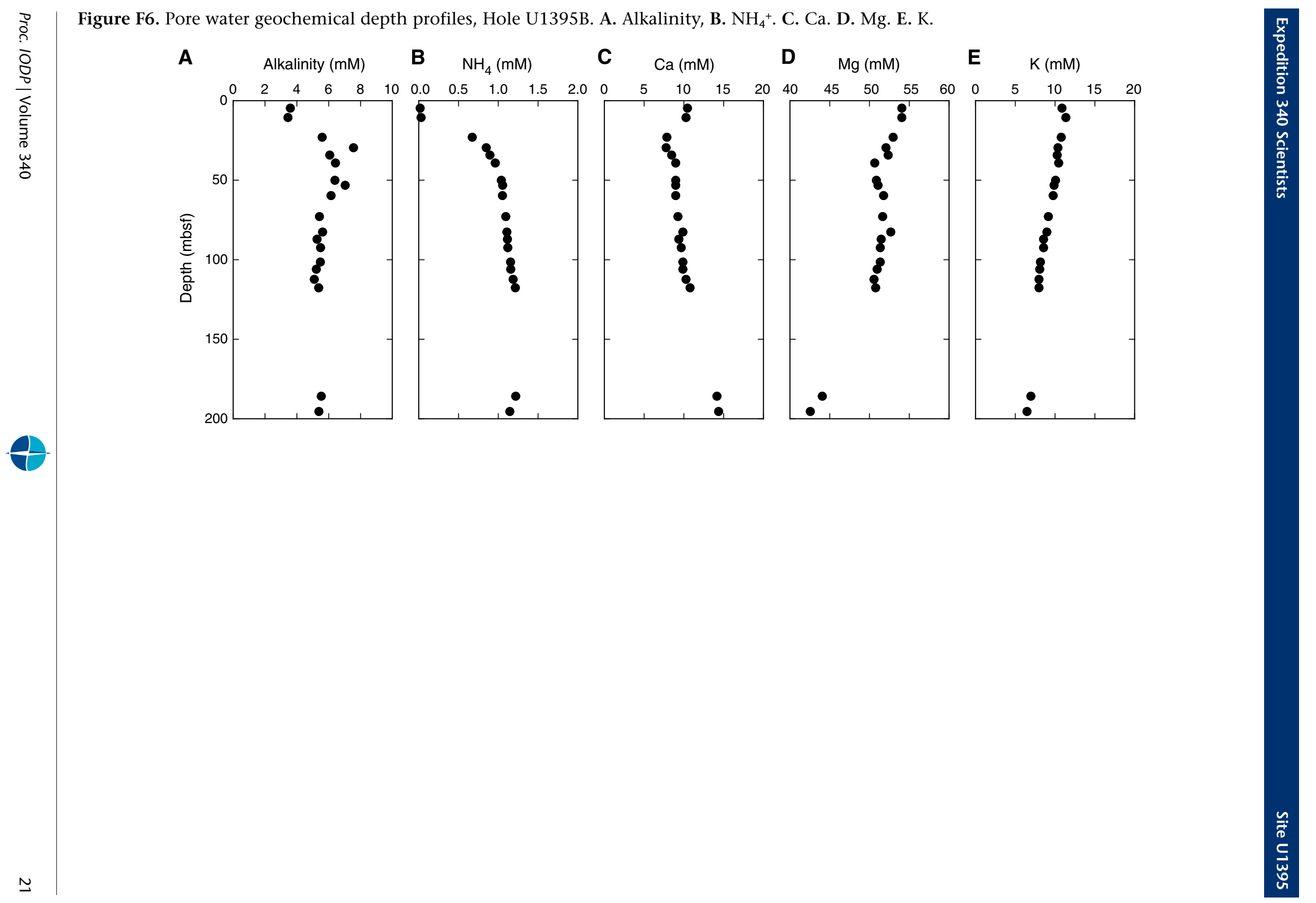


Figure F7. Magnetic susceptibility correlation, Hole U1395B (blue) to Hole U1395A (red). Magnetic susceptibility was measured on the WholeRound Multisensor Logger (WRMSL). Negative values in the last column indicate a downhole shift. A. 0-50 mbsf. (Continued on next page.)

A

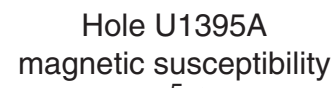

$\left(10^{-5} \mathrm{SI}\right)$

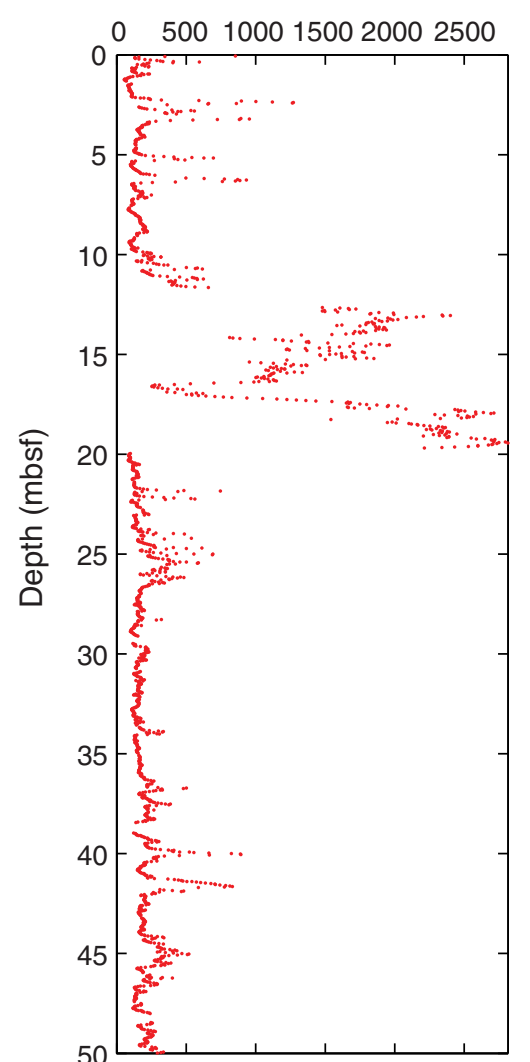

Hole U1395B magnetic susceptibility

$\left(10^{-5} \mathrm{SI}\right)$

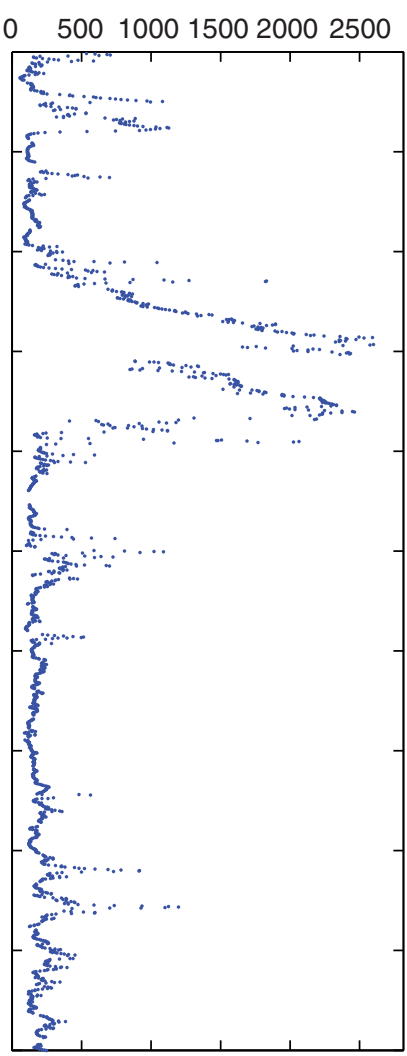

Correlated magnetic susceptibility Hole U1395B to Hole U1395A

$$
\left(10^{-5} \mathrm{SI}\right)
$$

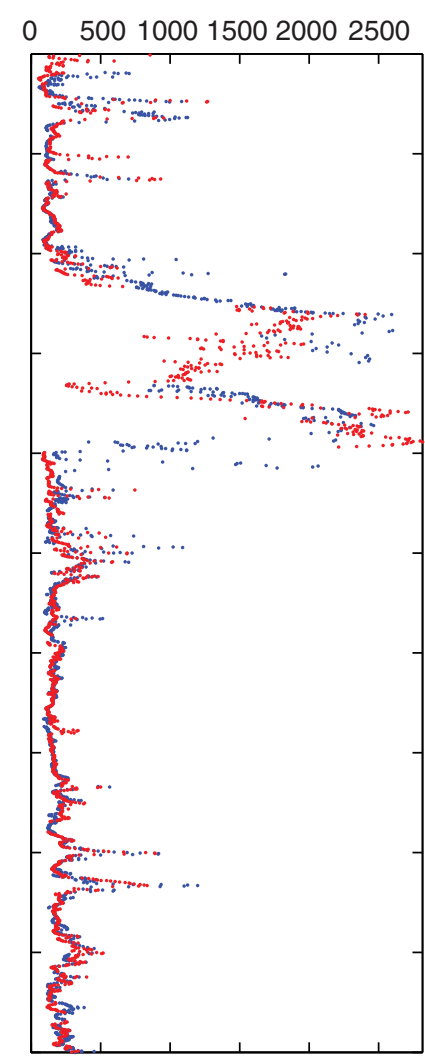

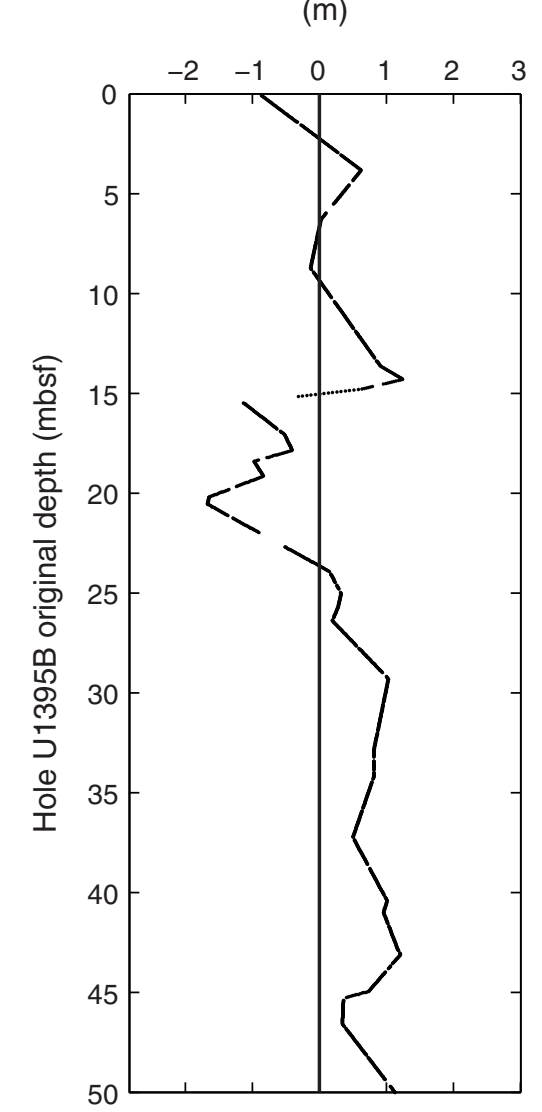

Hole U1395B shift in depth

(m) 
Figure F7 (continued). B. 50-120 mbsf.

B $\begin{gathered}\text { Hole U1395A } \\ \text { magnetic susceptibility }\end{gathered}$ $\left(10^{-5} \mathrm{SI}\right)$

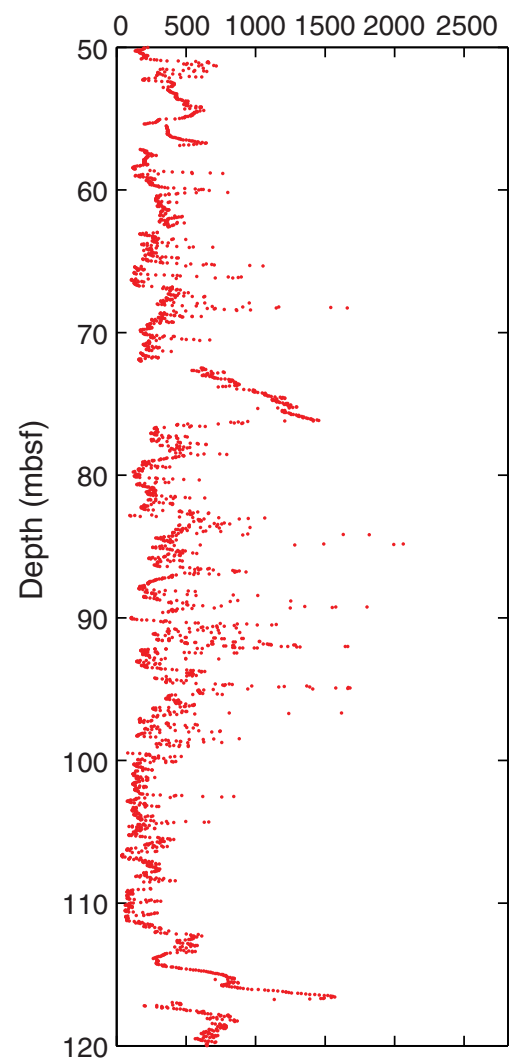

Hole U1395B

magnetic susceptibility

$\left(10^{-5} \mathrm{SI}\right)$

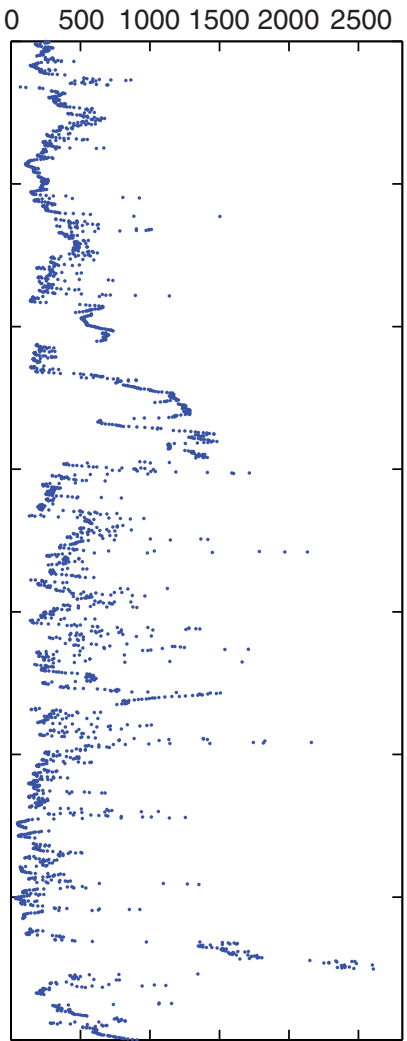

Correlated magnetic susceptibility Hole U1395B to Hole U1395A $\left(10^{-5} \mathrm{SI}\right)$

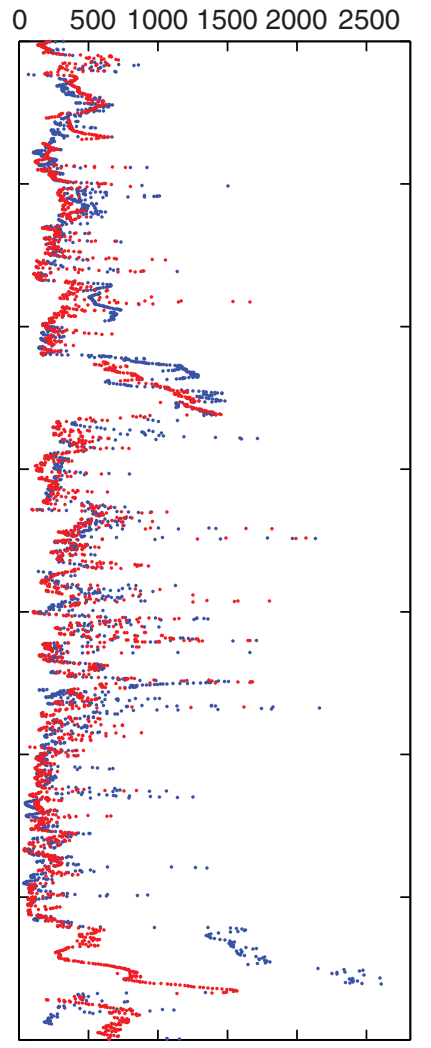

Hole U1395B shift in depth

(m)

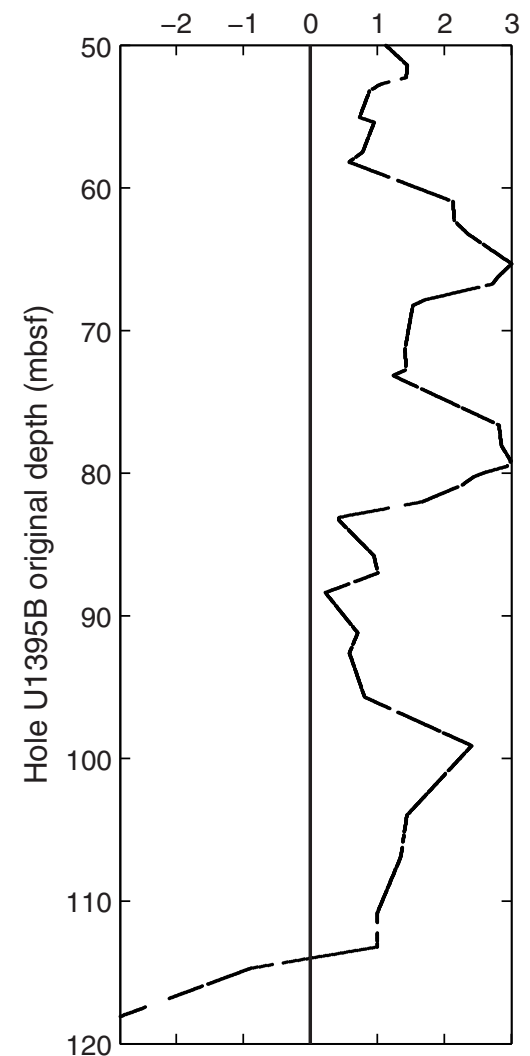


Figure F8. Physical properties, Holes U1395A (red) and U1395B (blue). Whole-core data were excluded at both extremities of each core section to avoid core liner disturbances. Whole-Round Multisensor Logger (WRMSL) $P$-wave velocities were truncated when below $1500 \mathrm{~m} / \mathrm{s}$, corresponding to velocity in water. Discrete point measurements are shown with larger symbols. Vertical dashed line in the shear strength plot shows the maximum value that can be measured with the handheld penetrometer $(220 \mathrm{kPa})$. AVS = automated vane shear.

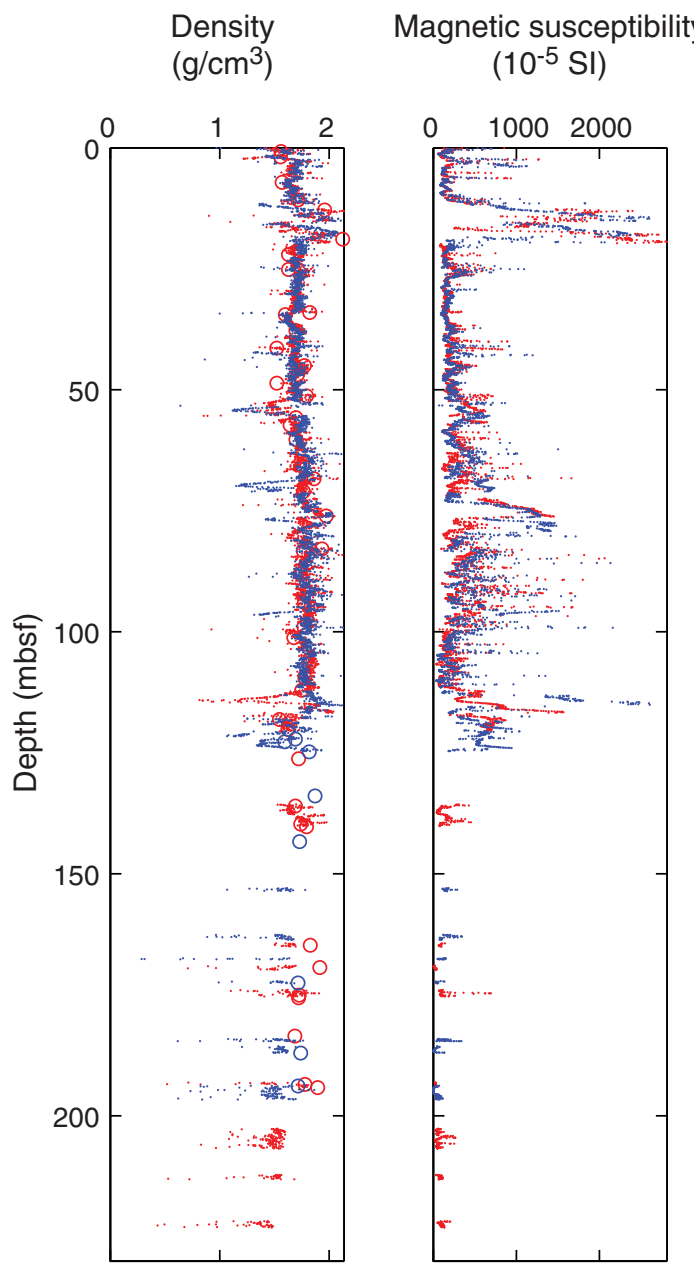

Natural gamma radiation (cps)

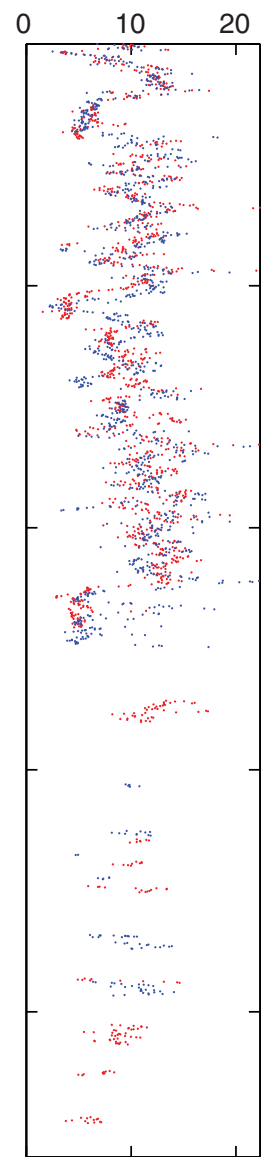

$P$-wave velocity

$(\mathrm{m} / \mathrm{s})$

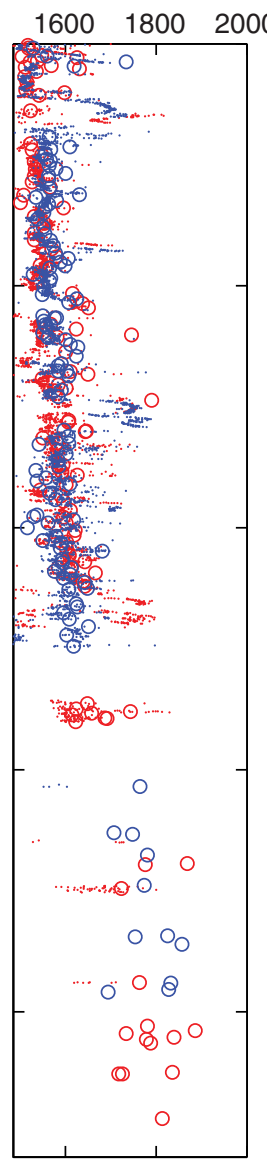

O P-wave $\mathrm{x}$
Shear strength (kPa)

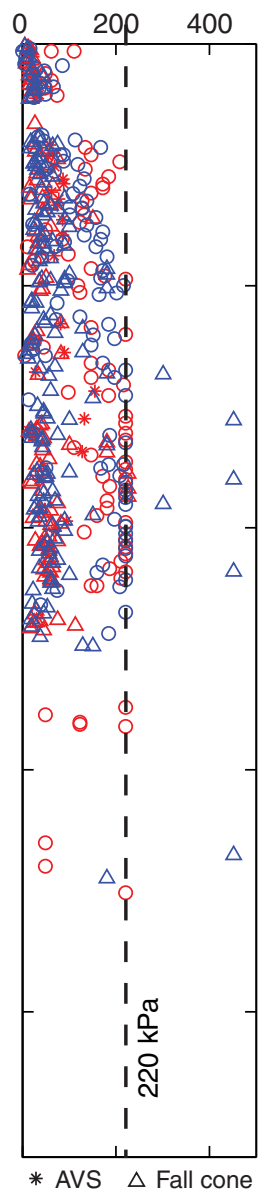

Porosity

(\%)

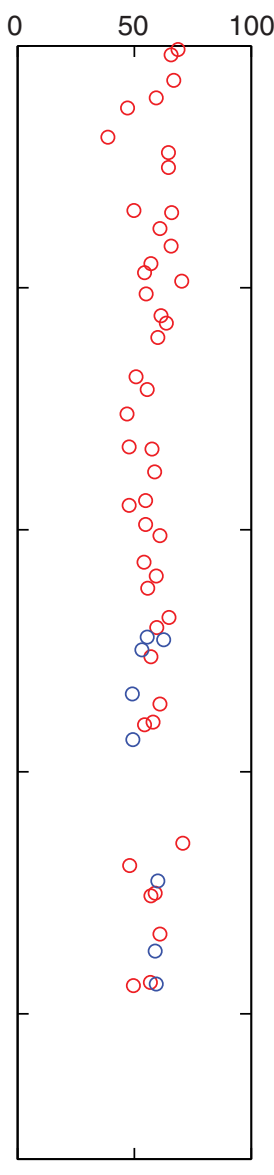

Thermal conductivity (W/[m.K])

\begin{tabular}{|c|c|}
\hline & 1 \\
\hline 0 & 0 \\
& 0 \\
0 & 8 \\
0 & 0 \\
0 & \\
0 & \\
0 & \\
0 & 0 \\
0 & 0 \\
8 & \\
0 \\
8 \\
\end{tabular}


Figure F9. Temperature as a function of depth, Hole U1395B. Uppermost point is ocean water temperature at the seafloor. Straight line is a best fit to the measurements.

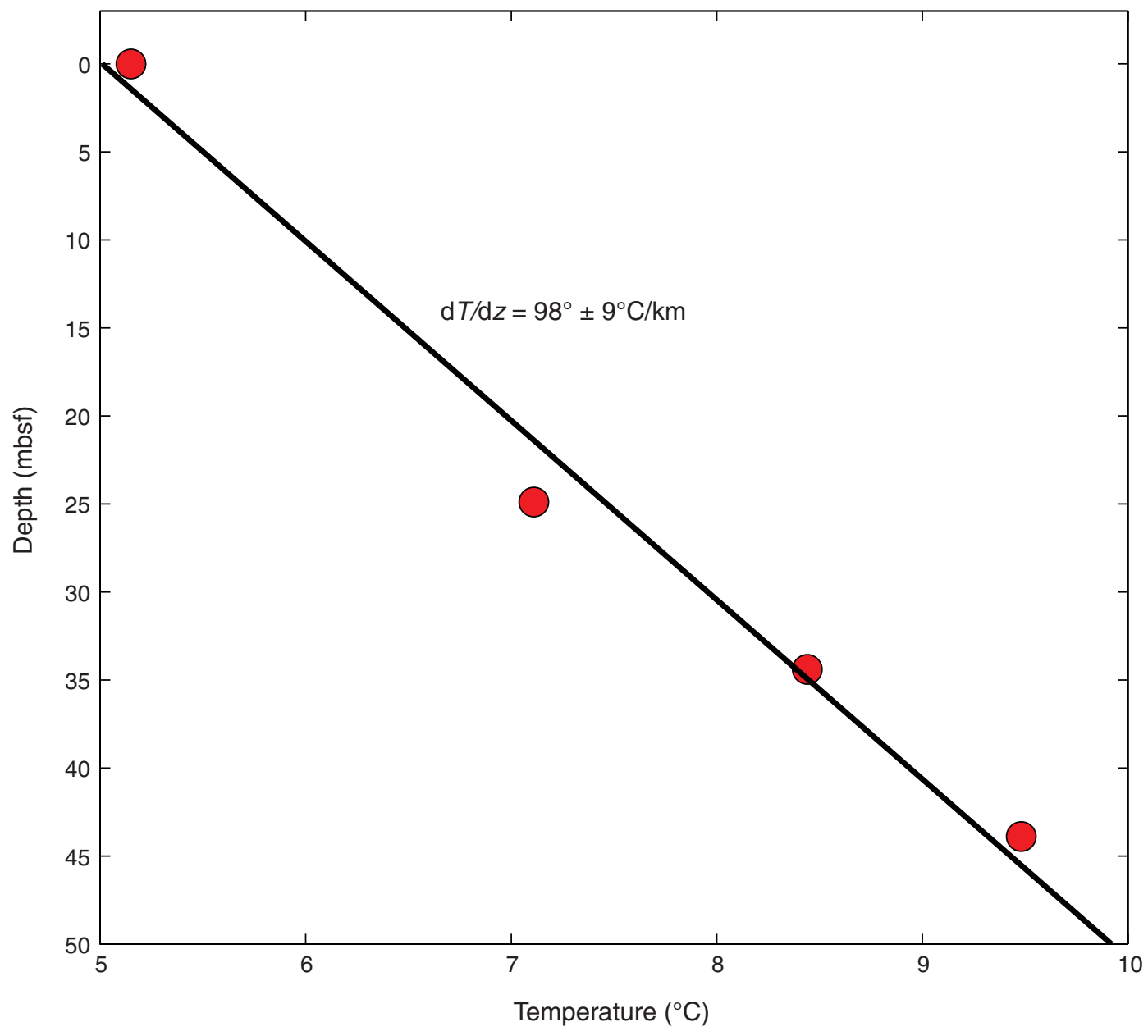


Figure F10. Plots of intensity of $\mathrm{NRM}_{0}$ (red) and $\mathrm{NRM}_{20}$ (blue) and inclination and declination after $20 \mathrm{mT}$ demagnetization, Hole U1395A. For inclination data, gray points are all measurements made and red data are data from hemipelagic sediment. For declination data, gray points are unoriented declinations, red points are FlexIt tool-corrected data on hemipelagic sediment, and orange points are from hemipelagic sediment rotated and guided by discrete inclination data. Black squares are discrete declination and inclination measurements shown against a geocentric axial dipole (GAD) inclination of $30.6^{\circ}$.

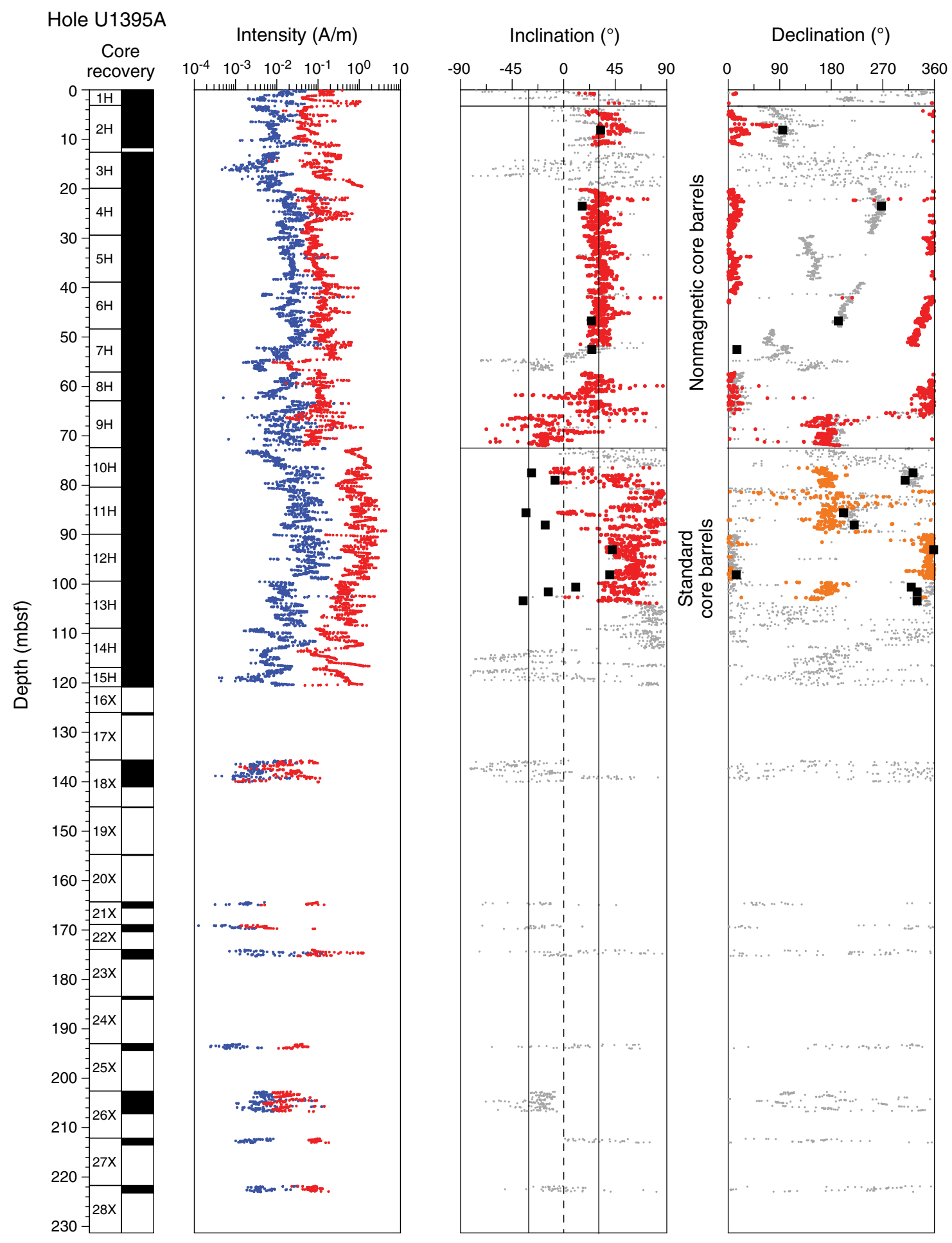


Figure F11. Plots of intensity of $\mathrm{NRM}_{0}$ (red) and $\mathrm{NRM}_{20}$ (blue) and inclination and declination after $20 \mathrm{mT}$ demagnetization, Hole U1395B. For inclination data, gray points are all measurements made and red data are data from hemipelagic sediment. For declination data, gray points are unoriented declinations and orange points are from hemipelagic sediment rotated and guided by discrete inclination data. Black squares are discrete declination and inclination measurements shown against a geocentric axial dipole (GAD) inclination of $30.6^{\circ}$.

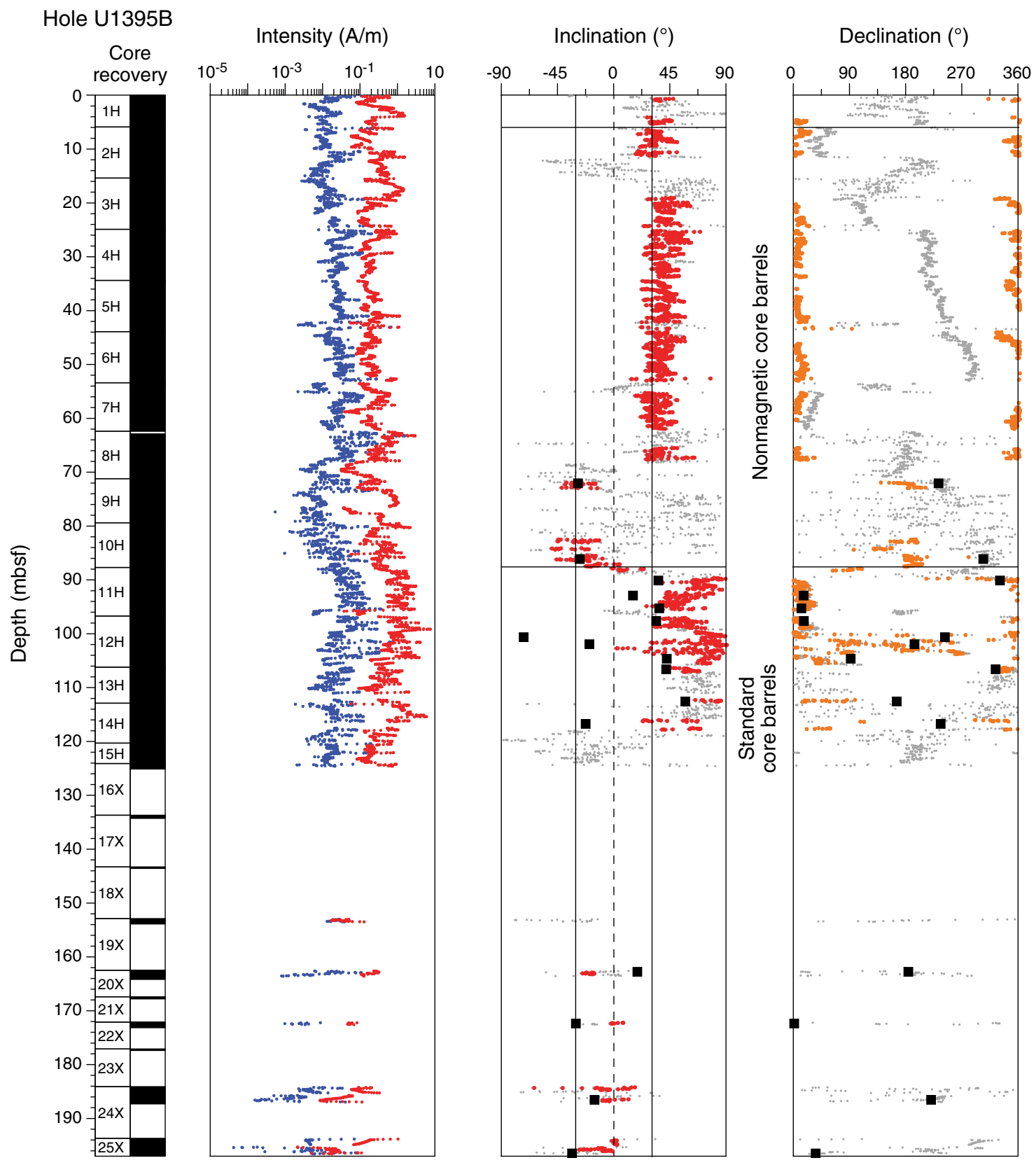


Figure F12. Magnetic susceptibility correlations used to transfer Hole U1395B depths onto Hole U1395A depths. The composite inclination record is shown on Hole U1395A depth.

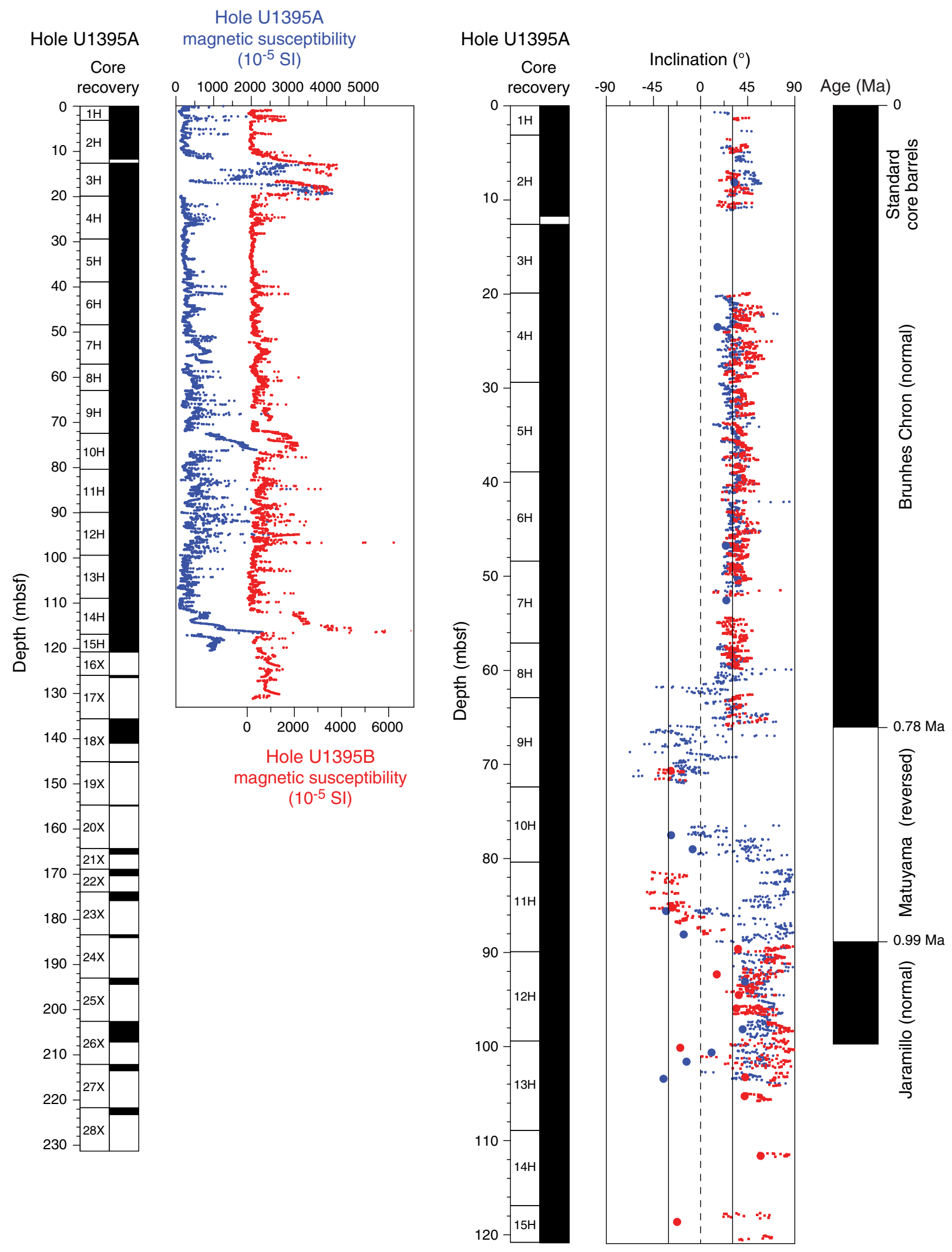


Figure F13. Integrated data from planktonic and benthic foraminiferal biostratigraphy, nannofossil biostratigraphy, and paleomagnetic age, Site U1395.

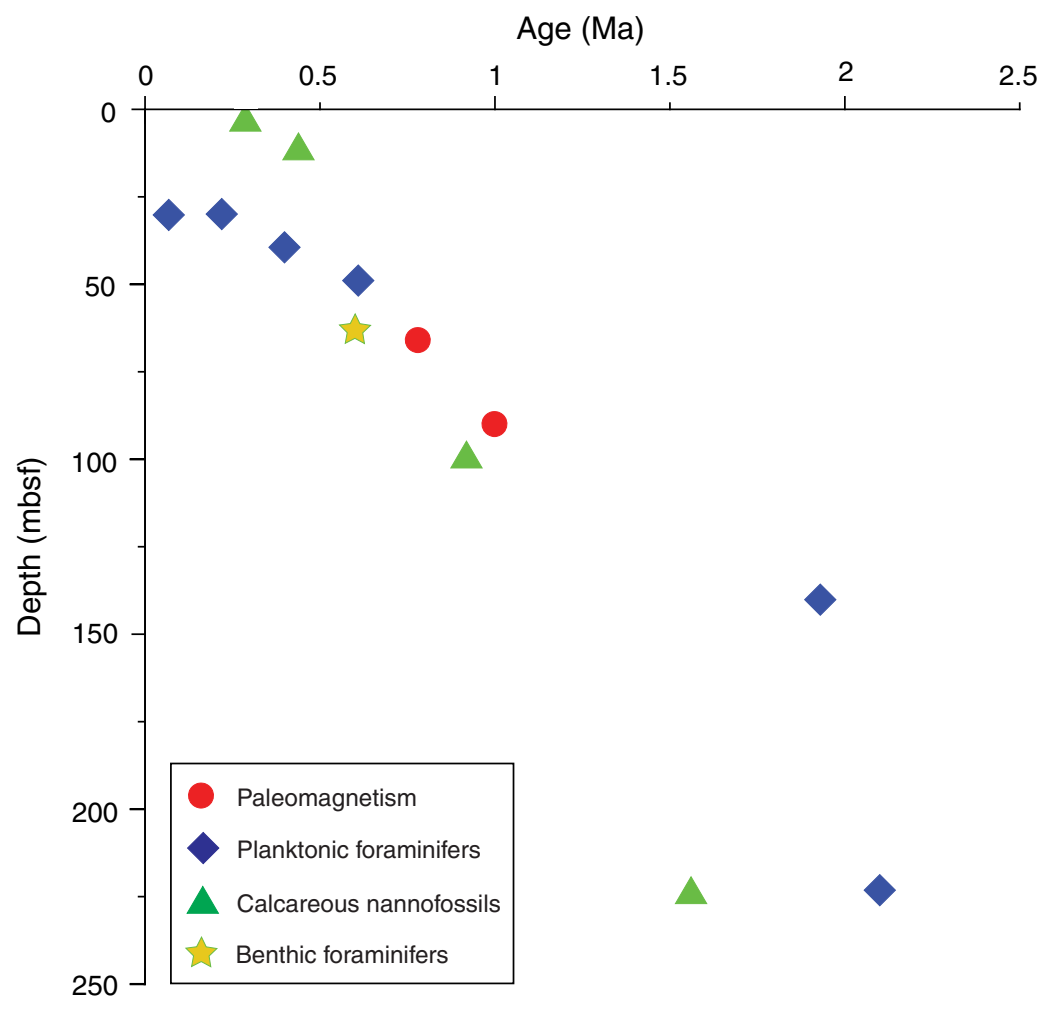


Figure F14. Schematic of tool deployments in Hole U1395B. MSS = Magnetic Susceptibility Sonde, FMS = Formation MicroScanner.

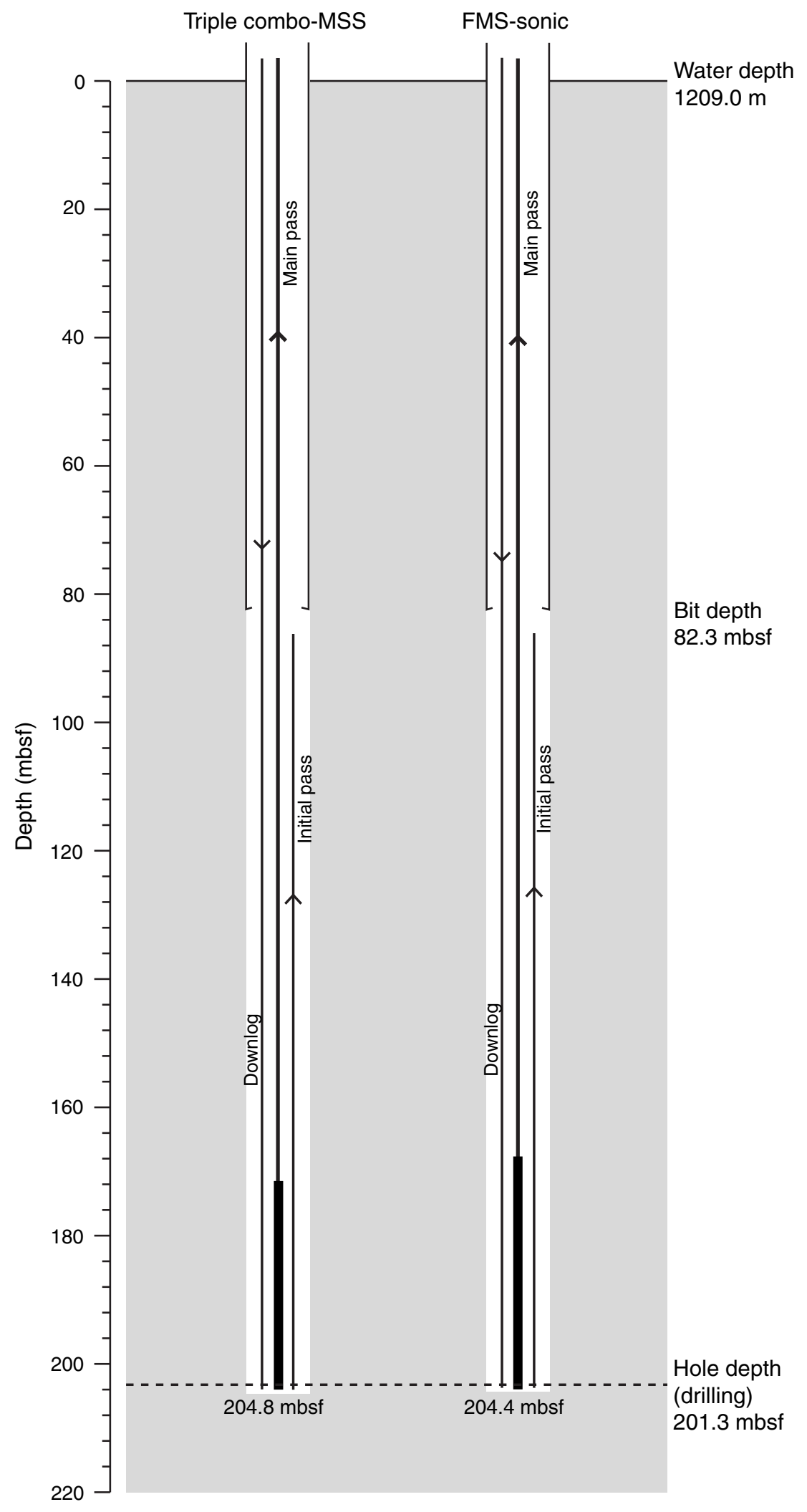


Figure F15. Summary of logs recorded by the triple combo tool string and comparison to physical properties measured on recovered cores, Hole U1395B. NGR = natural gamma radiation measured on cores, MAD = moisture and density core data. High-Resolution Laterolog Array (HRLA) readings: R3 = medium resistivity, $\mathrm{R} 5$ = deepest resistivity, RT = true resistivity, modeled from all depths of investigation.

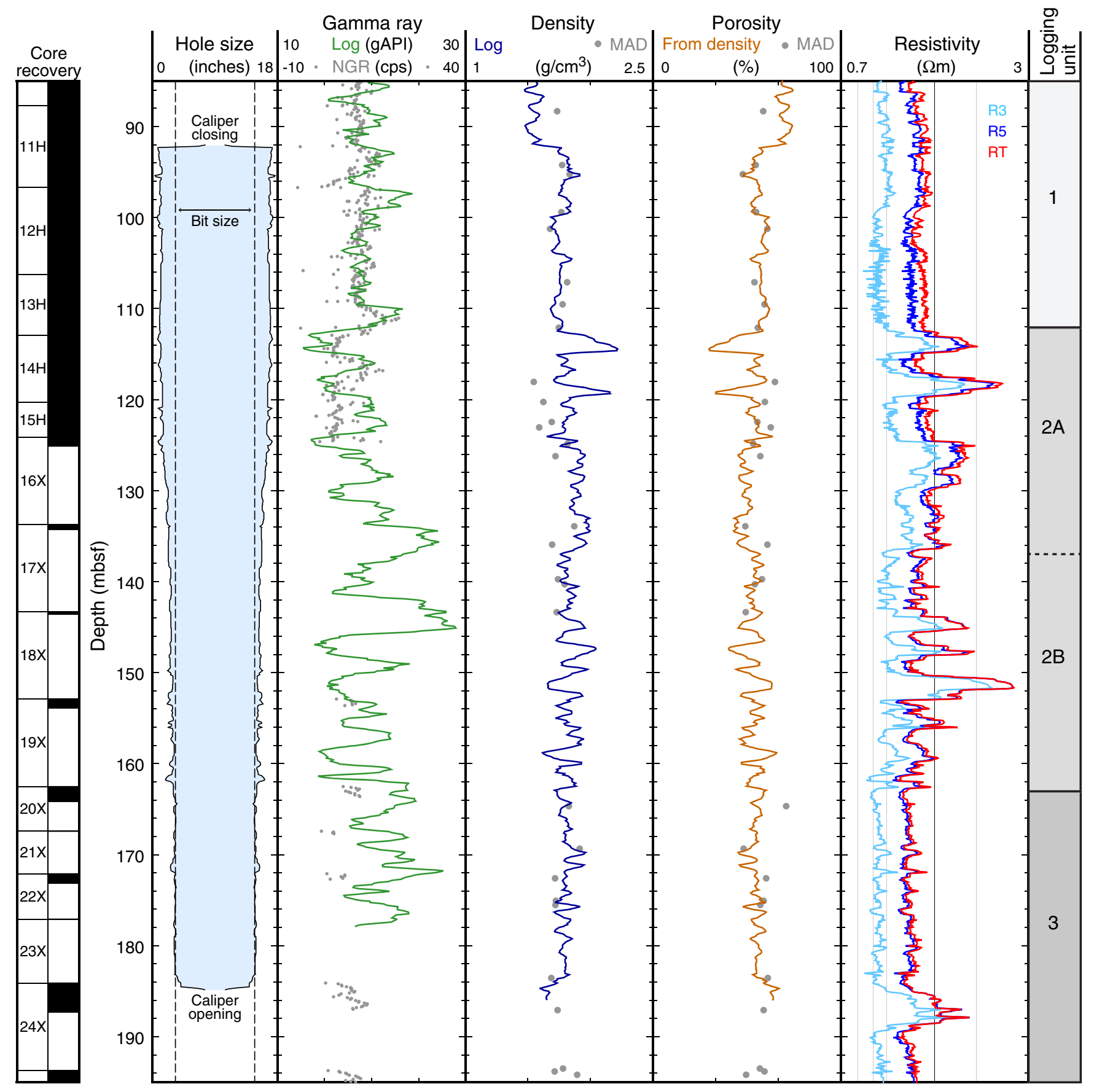


Figure F16. Summary of logs recorded by the Formation MicroScanner (FMS)-sonic tool string, Hole U1395B. Hole size is measured by the two orthogonal calipers of the FMS (C1 and C2). Gamma ray recorded during the FMS-sonic run (FMS) is compared to gamma ray recorded by the triple combo run (TC). The high waveform coherence, in red in the velocity tracks, is a measure of the reliability of the slowness/time coherence algorithm used to derive compressional $\left(V_{\mathrm{P}}\right)$ and shear $\left(V_{S}\right)$ wave velocities from the monopole and lower dipole sonic waveforms, respectively.

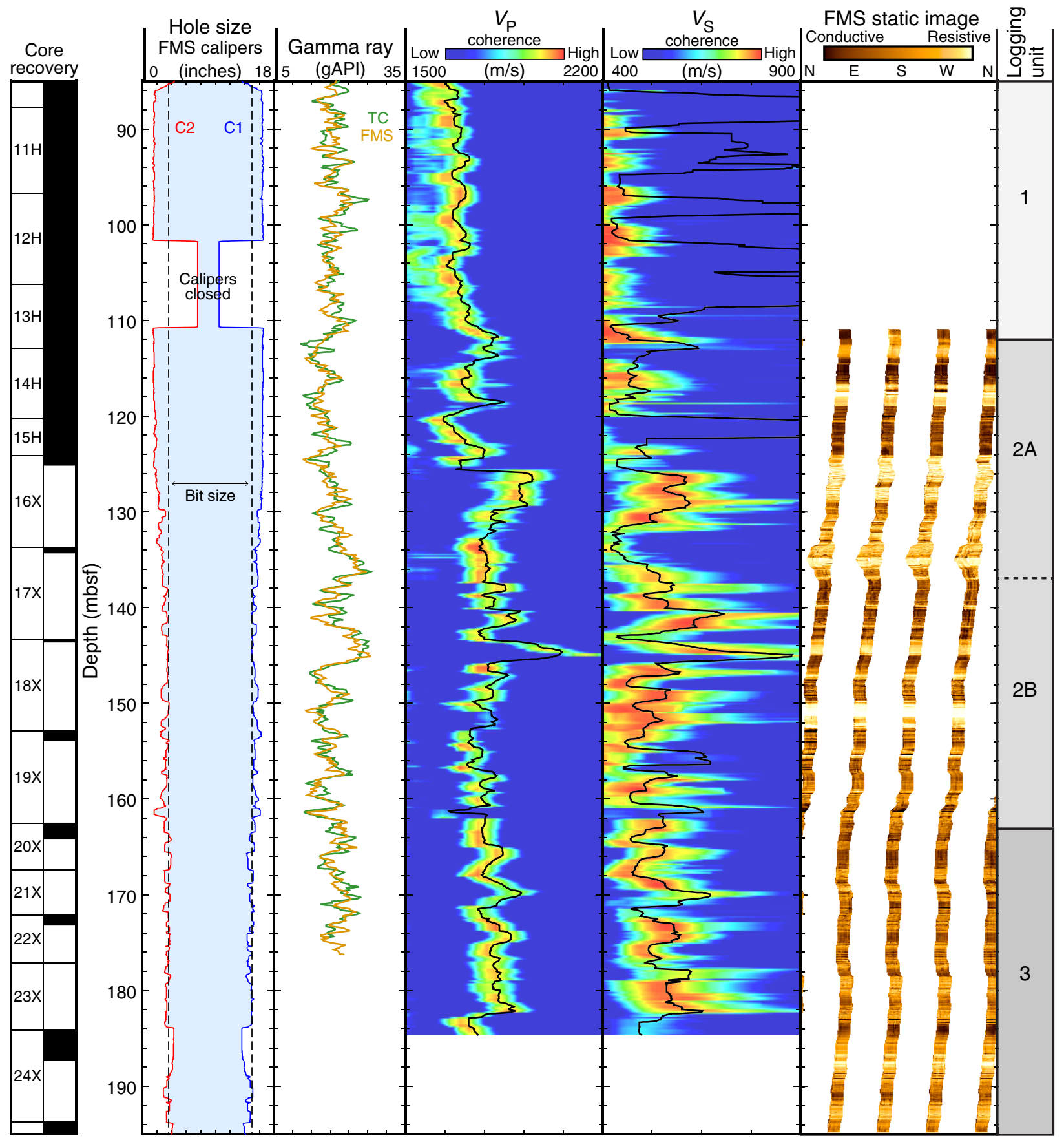


Figure F17. Comparison of some of the main logs recorded during multiple logging passes, Hole U1395B. All data sets show good agreement between the two passes, indicating the reliability of the various measurements.

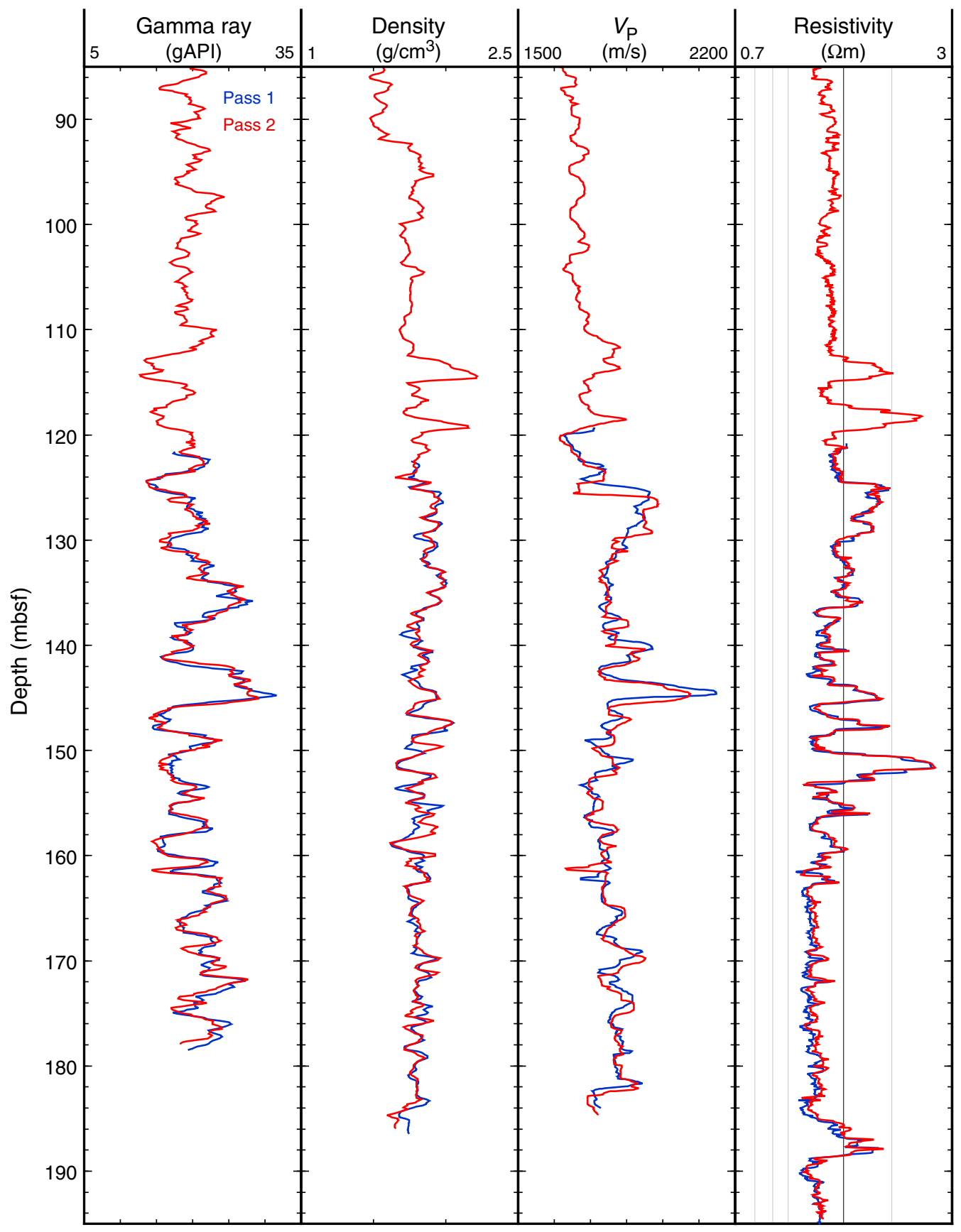


Figure F18. Summary of spectral natural gamma radiation measurements, Hole U1395B. SGR = total gamma ray, $\mathrm{CGR}=$ computed gamma ray or gamma ray without the contribution of uranium. The area between the two curves shows the contribution of uranium, a common indicator of organic content.

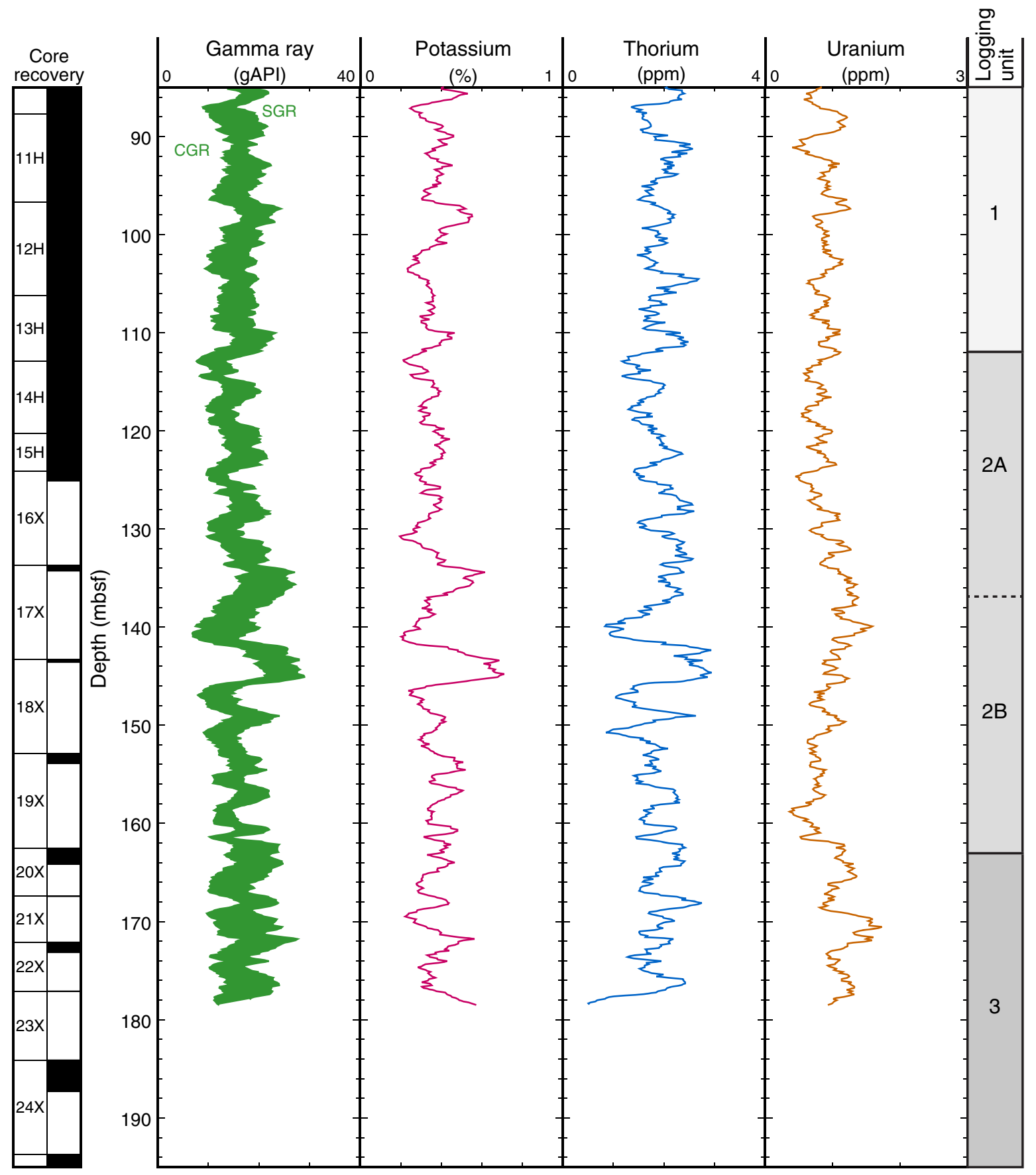


Figure F19. Examples of statically processed FMS images, Hole U1395B. A. Dipping boundary highlighted by the resistivity contrast, logging Subunit 2A. B. Textural variation across a gently dipping boundary, logging Unit 2. C. Textural variation within a highly resistive interval, logging Subunit $2 \mathrm{~A}$.
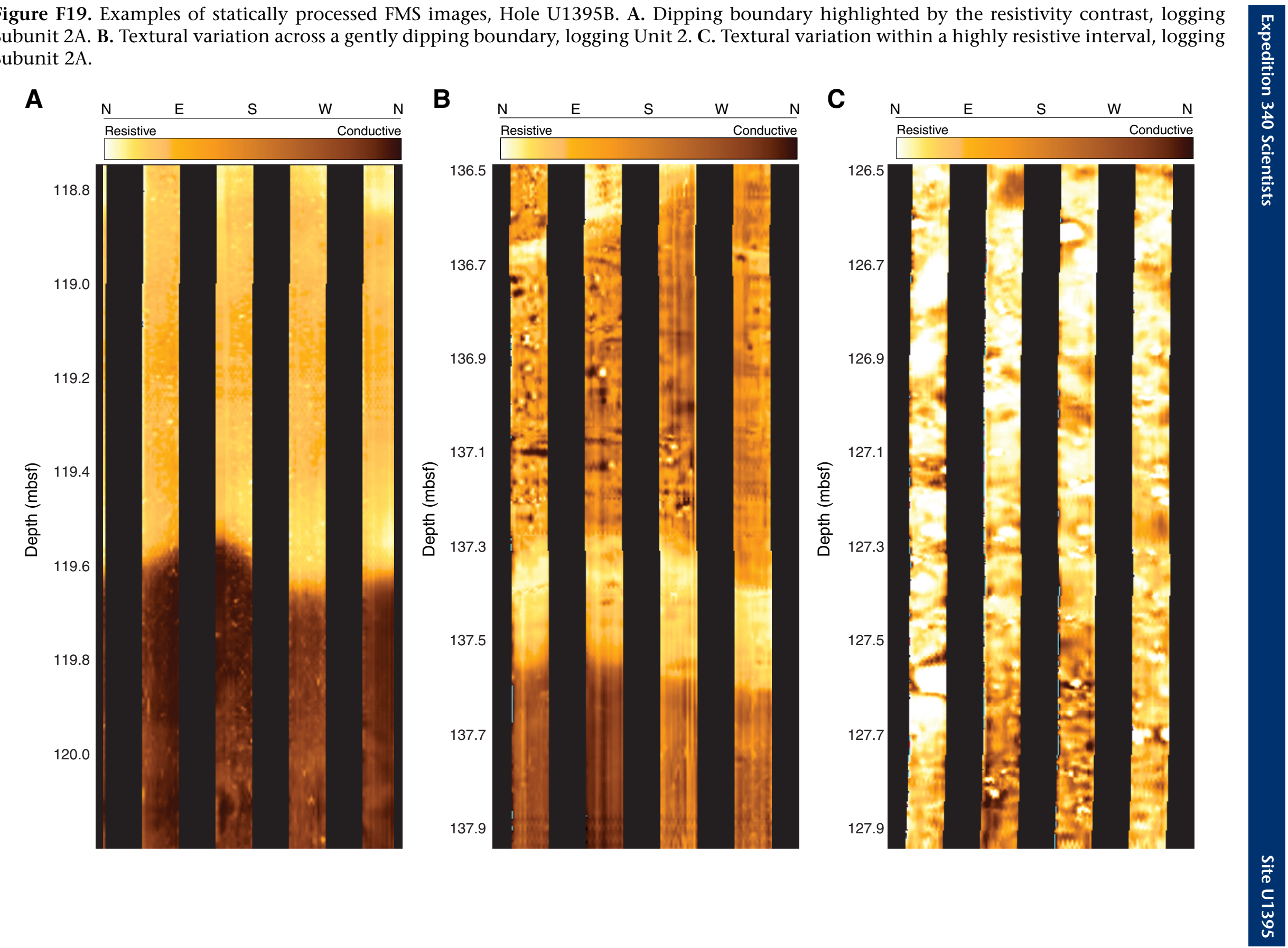
Table T1. Coring summary, Site U1395. (Continued on next page.)

\begin{tabular}{ll}
\hline Hole: & U1395A \\
Latitude: & $16^{\circ} 29.5988^{\prime} \mathrm{N}$ \\
Longitude: & $61^{\circ} 57.0858^{\prime} \mathrm{W}$ \\
Water depth (m): & 1200.9 \\
Date started (UTC*): & 2300 h 12 March 2012 \\
Date finished (UTC*): & 1400 h 14 March 2012 \\
Time on hole (days): & 1.6 \\
Seafloor depth DRF (m): & 1212.4 \\
Penetration DSF (m): & 231.3 \\
Cored interval (m): & 231.3 \\
Recovered length (m): & 144.18 \\
Recovery (\%): & 62 \\
Total cores (no.): & 28 \\
Hole: & U1395B \\
Latitude: & $16^{\circ} 29.5985^{\prime} \mathrm{N}$ \\
Longitude: & $61^{\circ} 57.0751^{\prime} \mathrm{W}$ \\
Water depth (m): & 1200.2 \\
Date started (UTC*): & $1400 \mathrm{~h} 14$ March 2012 \\
Date finished (UTC*): & $1600 \mathrm{~h} \mathrm{16} \mathrm{March} 2012$ \\
Time on hole (days): & 1.23 \\
Seafloor depth DRF (m): & 1211.6 \\
Penetration DSF (m): & 203.3 \\
Cored interval (m): & 203.3 \\
Recovered length (m): & 140.21 \\
Recovery (\%): & 69 \\
Total cores (no.): & 25 \\
& \\
\hline
\end{tabular}

\begin{tabular}{|c|c|c|c|c|c|c|c|c|c|}
\hline Core & $\begin{array}{l}\text { Top depth } \\
\text { drilled } \\
\text { DSF }(m)\end{array}$ & $\begin{array}{l}\text { Bottom depth } \\
\text { drilled } \\
\text { DSF }(\mathrm{m})\end{array}$ & $\begin{array}{l}\text { Advanced } \\
\text { (m) }\end{array}$ & $\begin{array}{l}\text { Recovered } \\
\text { length } \\
(\mathrm{m})\end{array}$ & $\begin{array}{l}\text { Curated } \\
\text { length } \\
\text { (m) }\end{array}$ & $\begin{array}{l}\text { Top depth } \\
\text { cored } \\
\text { CSF }(\mathrm{m})\end{array}$ & $\begin{array}{l}\text { Bottom depth } \\
\text { recovered } \\
\text { CSF }(m)\end{array}$ & $\begin{array}{l}\text { Recovery } \\
\text { (\%) }\end{array}$ & $\begin{array}{l}\text { Time on deck } \\
\left(\text { UTC }^{*}\right)\end{array}$ \\
\hline \multicolumn{10}{|c|}{ 340-U1395A- } \\
\hline $1 \mathrm{H}$ & 0.0 & 3.1 & 3.1 & 3.35 & 3.35 & 0.0 & 3.35 & 108 & $3 / 13 / 1213: 05$ \\
\hline $2 \mathrm{H}$ & 3.1 & 12.6 & 9.5 & 8.64 & 8.64 & 3.1 & 11.74 & 91 & $3 / 13 / 1213: 55$ \\
\hline $3 \mathrm{H}$ & 12.6 & 19.9 & 7.3 & 7.31 & 7.31 & 12.6 & 19.91 & 100 & $3 / 13 / 1214: 45$ \\
\hline $4 \mathrm{H}$ & 19.9 & 29.4 & 9.5 & 10.06 & 10.06 & 19.9 & 29.96 & 106 & $3 / 13 / 1215: 45$ \\
\hline $5 \mathrm{H}$ & 29.4 & 38.9 & 9.5 & 10.13 & 10.13 & 29.4 & 39.53 & 107 & $3 / 13 / 1216: 20$ \\
\hline $6 \mathrm{H}$ & 38.9 & 48.4 & 9.5 & 10.08 & 10.08 & 38.9 & 48.98 & 106 & $3 / 13 / 1217: 00$ \\
\hline $7 \mathrm{H}$ & 48.4 & 57.1 & 8.7 & 8.74 & 8.74 & 48.4 & 57.14 & 100 & $3 / 13 / 1217: 35$ \\
\hline $8 \mathrm{H}$ & 57.1 & 62.9 & 5.8 & 5.81 & 5.81 & 57.1 & 62.91 & 100 & $3 / 13 / 1218: 35$ \\
\hline $9 \mathrm{H}$ & 62.9 & 72.4 & 9.5 & 10.15 & 10.15 & 62.9 & 73.05 & 107 & $3 / 13 / 1219: 25$ \\
\hline $10 \mathrm{H}$ & 72.4 & 80.4 & 8.0 & 8.06 & 8.06 & 72.4 & 80.46 & 101 & $3 / 13 / 1220: 30$ \\
\hline $11 \mathrm{H}$ & 80.4 & 89.9 & 9.5 & 9.86 & 9.86 & 80.4 & 90.26 & 104 & $3 / 13 / 1222: 30$ \\
\hline $12 \mathrm{H}$ & 89.9 & 99.4 & 9.5 & 10.06 & 10.06 & 89.9 & 99.96 & 106 & $3 / 14 / 12$ 23:50 \\
\hline $13 \mathrm{H}$ & 99.4 & 108.9 & 9.5 & 10.05 & 10.05 & 99.4 & 109.45 & 106 & $3 / 14 / 1200: 40$ \\
\hline $14 \mathrm{H}$ & 108.9 & 116.9 & 8.0 & 8.02 & 8.02 & 108.9 & 116.92 & 100 & $3 / 14 / 1201: 25$ \\
\hline $15 \mathrm{H}$ & 116.9 & 120.8 & 3.9 & 3.97 & 3.97 & 116.9 & 120.87 & 102 & $3 / 14 / 12$ 02:15 \\
\hline $16 X$ & 120.8 & 126.0 & 5.2 & 0.00 & 0.00 & 120.8 & 120.80 & 0 & $3 / 14 / 1203: 45$ \\
\hline $17 X$ & 126.0 & 135.6 & 9.6 & 0.50 & 0.50 & 126.0 & 126.50 & 5 & $3 / 14 / 1204: 40$ \\
\hline $18 \mathrm{X}$ & 135.6 & 145.1 & 9.5 & 4.94 & 4.94 & 135.6 & 140.54 & 52 & $3 / 14 / 12$ 05:55 \\
\hline $19 x$ & 145.1 & 154.7 & 9.6 & 0.16 & 0.16 & 145.1 & 145.26 & 2 & $3 / 14 / 1207: 10$ \\
\hline $20 x$ & 154.7 & 164.3 & 9.6 & 0.23 & 0.23 & 154.7 & 154.93 & 2 & $3 / 14 / 1208: 40$ \\
\hline $21 x$ & 164.3 & 168.9 & 4.6 & 1.29 & 1.29 & 164.3 & 165.59 & 28 & $3 / 14 / 1210: 30$ \\
\hline $22 x$ & 168.9 & 173.9 & 5.0 & 1.48 & 1.48 & 168.9 & 170.38 & 30 & $3 / 14 / 1211: 55$ \\
\hline $23 x$ & 173.9 & 183.4 & 9.5 & 1.98 & 1.98 & 173.9 & 175.88 & 21 & $3 / 14 / 1213: 10$ \\
\hline $24 X$ & 183.4 & 193.0 & 9.6 & 0.33 & 0.33 & 183.4 & 183.73 & 3 & $3 / 14 / 1214: 30$ \\
\hline $25 X$ & 193.0 & 202.6 & 9.6 & 1.41 & 1.41 & 193.0 & 194.41 & 15 & $3 / 14 / 1216: 25$ \\
\hline $26 x$ & 202.6 & 212.1 & 9.5 & 4.59 & 4.59 & 202.6 & 207.19 & 48 & $3 / 14 / 1217: 45$ \\
\hline $27 X$ & 212.1 & 221.7 & 9.6 & 1.43 & 1.43 & 212.1 & 213.53 & 15 & $3 / 14 / 1218: 50$ \\
\hline $28 \mathrm{X}$ & 221.7 & 231.3 & 9.6 & 1.55 & 1.55 & 221.7 & 223.25 & 16 & $3 / 14 / 12$ 20:00 \\
\hline \multicolumn{10}{|c|}{ 340-U1395B- } \\
\hline $1 \mathrm{H}$ & 0.0 & 5.9 & 5.9 & 5.90 & 5.90 & 0.0 & 5.90 & 100 & $3 / 14 / 12$ 23:40 \\
\hline $2 \mathrm{H}$ & 5.9 & 15.4 & 9.5 & 9.63 & 9.63 & 5.9 & 15.53 & 101 & $3 / 15 / 1200: 30$ \\
\hline $3 \mathrm{H}$ & 15.4 & 24.9 & 9.5 & 9.86 & 9.86 & 15.4 & 25.26 & 104 & $3 / 15 / 1201: 25$ \\
\hline $4 \mathrm{H}$ & 24.9 & 34.4 & 9.5 & 10.22 & 10.22 & 24.9 & 35.12 & 108 & $3 / 15 / 1202: 15$ \\
\hline $5 \mathrm{H}$ & 34.4 & 43.9 & 9.5 & 9.86 & 9.86 & 34.4 & 44.26 & 104 & $3 / 15 / 1203: 00$ \\
\hline $6 \mathrm{H}$ & 43.9 & 53.4 & 9.5 & 9.99 & 9.99 & 43.9 & 53.89 & 105 & $3 / 15 / 1203: 30$ \\
\hline $7 \mathrm{H}$ & 53.4 & 62.4 & 9.0 & 9.01 & 9.01 & 53.4 & 62.41 & 100 & $3 / 15 / 1204: 05$ \\
\hline $8 \mathrm{H}$ & 62.4 & 71.2 & 8.8 & 8.82 & 8.82 & 62.4 & 71.22 & 100 & $3 / 15 / 1204: 55$ \\
\hline $9 \mathrm{H}$ & 71.2 & 79.4 & 8.2 & 8.26 & 8.26 & 71.2 & 79.46 & 101 & $3 / 15 / 1205: 55$ \\
\hline $10 \mathrm{H}$ & 79.4 & 87.7 & 8.3 & 8.33 & 8.33 & 79.4 & 87.73 & 100 & $3 / 15 / 12$ 07:15 \\
\hline
\end{tabular}


Table T1 (continued).

\begin{tabular}{|c|c|c|c|c|c|c|c|c|c|}
\hline Core & $\begin{array}{l}\text { Top depth } \\
\text { drilled } \\
\text { DSF }(\mathrm{m})\end{array}$ & $\begin{array}{l}\text { Bottom depth } \\
\text { drilled } \\
\text { DSF }(\mathrm{m})\end{array}$ & $\begin{array}{l}\text { Advanced } \\
(\mathrm{m})\end{array}$ & $\begin{array}{l}\text { Recovered } \\
\text { length } \\
(\mathrm{m})\end{array}$ & $\begin{array}{l}\text { Curated } \\
\text { length } \\
(\mathrm{m})\end{array}$ & $\begin{array}{l}\text { Top depth } \\
\text { cored } \\
\text { CSF }(m)\end{array}$ & $\begin{array}{l}\text { Bottom depth } \\
\text { recovered } \\
\text { CSF }(\mathrm{m})\end{array}$ & $\begin{array}{l}\text { Recovery } \\
\text { (\%) }\end{array}$ & $\begin{array}{l}\text { Time on deck } \\
\text { (UTC*) }\end{array}$ \\
\hline $11 \mathrm{H}$ & 87.7 & 96.7 & 9.0 & 9.07 & 9.07 & 87.7 & 96.77 & 101 & $3 / 15 / 1208: 50$ \\
\hline $12 \mathrm{H}$ & 96.7 & 106.2 & 9.5 & 10.04 & 10.04 & 96.7 & 106.74 & 106 & $3 / 15 / 1210: 05$ \\
\hline $13 \mathrm{H}$ & 106.2 & 112.9 & 6.7 & 6.76 & 6.76 & 106.2 & 112.96 & 101 & $3 / 15 / 1211: 10$ \\
\hline $14 \mathrm{H}$ & 112.9 & 120.3 & 7.4 & 7.42 & 7.42 & 112.9 & 120.32 & 100 & $3 / 15 / 1211: 55$ \\
\hline $15 \mathrm{H}$ & 120.3 & 124.1 & 3.8 & 4.34 & 4.34 & 120.3 & 124.64 & 114 & $3 / 15 / 1212: 40$ \\
\hline $16 x$ & 124.1 & 133.7 & 9.6 & 1.01 & 1.01 & 124.1 & 125.11 & 11 & $3 / 15 / 1214: 30$ \\
\hline $17 X$ & 133.7 & 143.3 & 9.6 & 0.57 & 0.57 & 133.7 & 134.27 & 6 & $3 / 15 / 1216: 15$ \\
\hline $18 \mathrm{X}$ & 143.3 & 152.9 & 9.6 & 0.27 & 0.27 & 143.3 & 143.57 & 3 & $3 / 15 / 1218: 50$ \\
\hline $19 x$ & 152.9 & 162.5 & 9.6 & 0.99 & 0.99 & 152.9 & 153.89 & 10 & $3 / 15 / 12$ 20:00 \\
\hline $20 x$ & 162.5 & 167.4 & 4.9 & 1.67 & 1.67 & 162.5 & 164.17 & 34 & $3 / 15 / 1221: 50$ \\
\hline $21 x$ & 167.4 & 172.1 & 4.7 & 0.40 & 0.40 & 167.4 & 167.80 & 9 & $3 / 15 / 12$ 22:45 \\
\hline $22 x$ & 172.1 & 177.1 & 5.0 & 1.04 & 1.04 & 172.1 & 173.14 & 21 & $3 / 16 / 1200: 30$ \\
\hline $23 x$ & 177.1 & 184.1 & 7.0 & 0.27 & 0.27 & 177.1 & 177.37 & 4 & $3 / 16 / 1202: 05$ \\
\hline $24 X$ & 184.1 & 193.7 & 9.6 & 3.20 & 3.20 & 184.1 & 187.30 & 33 & $3 / 16 / 12$ 03:45 \\
\hline \multirow[t]{2}{*}{$25 X$} & 193.7 & 203.3 & 9.6 & 3.28 & 3.28 & 193.7 & 196.98 & 34 & $3 / 16 / 1205: 05$ \\
\hline & & Totals: & 434.6 & 284.39 & 284.39 & & & & \\
\hline
\end{tabular}

* = ship local time was Universal Time Coordinated (UTC) $-4 \mathrm{~h} . \mathrm{DRF}=$ drilling depth below rig floor, DSF = drilling depth below seafloor, CSF $=$ core depth below seafloor. $\mathrm{H}=$ advanced piston corer, $\mathrm{X}=$ extended core barrel. 
Table T2. Solid-phase geochemistry, Site U1395.

\begin{tabular}{|c|c|c|c|c|c|c|c|}
\hline \multirow{2}{*}{$\begin{array}{l}\text { Core, } \\
\text { section }\end{array}$} & \multicolumn{2}{|c|}{ Depth (mbsf) } & \multicolumn{4}{|c|}{ Carbon (wt\%) } & \multirow{2}{*}{$\begin{array}{c}\text { Nitrogen } \\
(\mathrm{wt} \%)\end{array}$} \\
\hline & Top & Bottom & $\mathrm{CaCO}_{3}$ & Inorganic & Total & Organic & \\
\hline \multicolumn{8}{|c|}{ 340-U1395A- } \\
\hline $1 \mathrm{H}-1$ & 0.85 & 0.86 & & & 7.83 & & 0.05 \\
\hline $1 \mathrm{H}-2$ & 2.05 & 2.06 & 73.9 & 8.9 & 9.78 & 0.91 & 0.01 \\
\hline $2 \mathrm{H}-3$ & 7.14 & 7.15 & 33.7 & 4.0 & 4.67 & 0.63 & 0.02 \\
\hline $2 \mathrm{H}-6$ & 10.67 & 10.68 & 12.9 & 1.5 & 1.73 & 0.18 & BD \\
\hline $4 \mathrm{H}-4$ & 25.36 & 25.37 & 44.2 & 5.3 & 5.9 & 0.60 & 0.02 \\
\hline $5 \mathrm{H}-4$ & 34.29 & 34.30 & 14.1 & 1.7 & 2.02 & 0.34 & 0.02 \\
\hline $5 \mathrm{H}-4$ & 34.80 & 34.81 & 44.2 & 5.3 & 6.03 & 0.74 & 0.03 \\
\hline $6 \mathrm{H}-2$ & 41.53 & 41.54 & 0.3 & 0.0 & 0.08 & 0.05 & BD \\
\hline $6 \mathrm{H}-5$ & 45.37 & 45.38 & 29.1 & 3.5 & 4.02 & 0.53 & 0.01 \\
\hline $6 \mathrm{H}-6$ & 47.35 & 47.36 & 11.6 & 1.4 & 1.71 & 0.32 & 0.01 \\
\hline $7 \mathrm{H}-1$ & 48.62 & 48.63 & 47.0 & 5.6 & 6.63 & 1.00 & 0.03 \\
\hline $7 \mathrm{H}-2$ & 51.25 & 51.26 & 29.6 & 3.6 & 4.10 & 0.55 & 0.01 \\
\hline $7 \mathrm{H}-6$ & 55.74 & 55.75 & 44.9 & 5.4 & 5.86 & 0.48 & 0.56 \\
\hline $8 \mathrm{H}-1$ & 57.28 & 57.29 & & & 6.20 & & 0.03 \\
\hline $8 \mathrm{H}-3$ & 60.23 & 60.24 & 53.3 & 6.4 & 7.24 & 0.85 & 0.02 \\
\hline $9 \mathrm{H}-4$ & 68.77 & 68.78 & 9.7 & 1.2 & 1.38 & 0.22 & 0.01 \\
\hline $9 \mathrm{H}-6$ & 71.55 & 71.56 & 43.6 & 5.2 & 5.95 & 0.72 & 0.01 \\
\hline $10 \mathrm{H}-3$ & 76.07 & 76.08 & 0.2 & 0.0 & 0.33 & 0.30 & BD \\
\hline $10 \mathrm{H}-3$ & 76.07 & 76.08 & 2.2 & 0.3 & & & \\
\hline $10 \mathrm{H}-4$ & 77.59 & 77.60 & 42.4 & 5.1 & 5.74 & 0.66 & 0.02 \\
\hline $11 \mathrm{H}-2$ & 82.93 & 82.94 & 53.5 & 6.4 & 7.25 & 0.84 & 0.01 \\
\hline $11 \mathrm{H}-2$ & 83.34 & 83.35 & 53.8 & 6.5 & 7.19 & 0.74 & $\mathrm{BD}$ \\
\hline $11 \mathrm{H}-6$ & 88.28 & 88.29 & 52.4 & 6.3 & 7.08 & 0.80 & 0.02 \\
\hline $12 \mathrm{H}-3$ & 94.20 & 94.21 & 35.8 & 4.3 & 4.92 & 0.63 & BD \\
\hline $12 \mathrm{H}-4$ & 95.19 & 95.20 & & & 0.61 & & BD \\
\hline $12 \mathrm{H}-7$ & 99.38 & 99.39 & 35.2 & 4.2 & 4.80 & 0.58 & 0.01 \\
\hline $13 \mathrm{H}-2$ & 101.22 & 101.23 & 55.0 & 6.6 & 7.48 & 0.88 & 0.02 \\
\hline $13 \mathrm{H}-6$ & 107.03 & 107.04 & 68.7 & 8.2 & 9.13 & 0.89 & 0.04 \\
\hline $14 \mathrm{H}-1$ & 109.50 & 109.51 & 70.0 & 8.4 & 9.64 & 1.25 & 0.03 \\
\hline $14 \mathrm{H}-1$ & 109.50 & 109.51 & 67.5 & 8.1 & 9.17 & 1.08 & 0.04 \\
\hline $14 \mathrm{H}-3$ & 112.06 & 112.07 & 42.7 & 5.1 & 5.63 & 0.51 & 0.01 \\
\hline $15 \mathrm{H}-3$ & 120.19 & 120.20 & 3.4 & 0.4 & 0.41 & $\mathrm{BD}$ & 0.74 \\
\hline $18 X-1$ & 135.99 & 136.00 & 54.2 & 6.5 & 7.26 & 0.76 & 0.33 \\
\hline $18 X-3$ & 139.18 & 139.19 & 5.3 & 0.6 & 0.97 & 0.33 & 1.06 \\
\hline $21 X-1$ & 164.64 & 164.65 & 57.9 & 6.9 & 7.80 & 0.86 & 0.39 \\
\hline $22 X-1$ & 169.29 & 169.30 & 78.0 & 9.3 & 10.33 & 0.98 & 0.58 \\
\hline $23 X-1$ & 175.00 & 175.01 & & & 6.88 & & 0.03 \\
\hline $23 \mathrm{X}-\mathrm{CC}$ & 175.49 & 175.50 & & & 0.64 & & 0.01 \\
\hline $24 \mathrm{X}-\mathrm{CC}$ & 183.51 & 183.52 & 66.3 & 7.9 & 8.89 & 0.94 & 0.03 \\
\hline $25 X-1$ & 193.49 & 193.495 & 76.1 & 9.1 & 10.09 & 0.97 & 0.02 \\
\hline $25 \mathrm{X}-\mathrm{CC}$ & 194.16 & 194.165 & 87.9 & 10.5 & 12.08 & 1.54 & 0.01 \\
\hline $25 \mathrm{X}-\mathrm{CC}$ & 194.16 & 194.165 & 87.5 & 10.5 & 11.76 & 1.27 & 0.79 \\
\hline $26 \mathrm{X}-1$ & 203.19 & 203.20 & 59.9 & 7.2 & 8.05 & 0.87 & 0.65 \\
\hline $26 \mathrm{X}-2$ & 204.09 & 204.10 & 66.0 & 7.9 & 8.84 & 0.93 & 0.01 \\
\hline $26 X-2$ & 204.09 & 204.10 & 62.7 & 7.5 & 8.33 & 0.81 & 0.63 \\
\hline $27 X-1$ & 212.58 & 212.585 & 62.4 & 7.5 & 7.97 & 0.49 & 1.02 \\
\hline $28 X-1$ & 222.44 & 222.45 & 40.0 & 4.8 & 5.49 & 0.69 & 0.71 \\
\hline \multicolumn{8}{|c|}{ 340-U1395B- } \\
\hline $15 \mathrm{H}-2$ & 122.44 & 122.45 & 3.6 & 0.4 & 0.55 & 0.11 & 0.01 \\
\hline $16 \mathrm{X}-\mathrm{CC}$ & 124.80 & 124.81 & 65.6 & 7.9 & 8.78 & 0.92 & 0.52 \\
\hline $17 \mathrm{X}-\mathrm{CC}$ & 133.88 & 133.89 & 12.6 & 1.5 & 1.73 & 0.22 & 0.01 \\
\hline $17 \mathrm{X}-\mathrm{CC}$ & 133.88 & 133.89 & 11.9 & 1.4 & 1.58 & 0.16 & 0.61 \\
\hline $18 \mathrm{X}-\mathrm{CC}$ & 143.35 & 143.36 & 13.8 & 1.7 & 1.87 & 0.21 & 0.01 \\
\hline $18 \mathrm{X}-\mathrm{CC}$ & 143.35 & 143.36 & 13.4 & 1.6 & 1.72 & 0.11 & 0.51 \\
\hline $22 X-1$ & 172.58 & 172.59 & 66.3 & 7.9 & 8.79 & 0.85 & 0.03 \\
\hline $22 X-1$ & 172.58 & 172.59 & 63.1 & 7.6 & 8.22 & 0.66 & 0.58 \\
\hline $24 X-2$ & 187.03 & 187.04 & 62.1 & 7.5 & 8.06 & 0.61 & 0.58 \\
\hline $25 X-1$ & 193.80 & 193.81 & 69.2 & 8.3 & 9.07 & 0.77 & 0.75 \\
\hline
\end{tabular}

$\mathrm{BD}=$ below detection, values reported as 0. Blank cells = not analyzed 
Table T3. Composition of interstitial pore water, Site U1395B.

\begin{tabular}{|c|c|c|c|c|c|c|c|c|c|c|c|c|c|c|c|c|c|c|}
\hline \multirow{2}{*}{$\begin{array}{l}\text { Core, } \\
\text { section }\end{array}$} & \multicolumn{2}{|c|}{ Depth (mbsf) } & \multirow{2}{*}{$\begin{array}{l}\text { Alkalinity } \\
(\mathrm{mM})\end{array}$} & \multirow[b]{2}{*}{$\mathrm{pH}$} & \multirow{2}{*}{$\begin{array}{c}\mathrm{Cl} \\
(\mathrm{mM})\end{array}$} & \multirow[b]{2}{*}{ \pm} & \multirow[b]{2}{*}{ Salinity } & \multirow{2}{*}{$\begin{array}{c}\mathrm{NH}_{4} \\
(\mathrm{mM})\end{array}$} & \multirow{2}{*}{$\begin{array}{c}\mathrm{Na} \\
(\mathrm{mM})\end{array}$} & \multirow[b]{2}{*}{ \pm} & \multirow{2}{*}{$\underset{(m M)}{M g}$} & \multirow[b]{2}{*}{ \pm} & \multirow{2}{*}{$\underset{(\mathrm{mM})}{\mathrm{K}}$} & \multirow[b]{2}{*}{ \pm} & \multirow{2}{*}{$\begin{array}{c}\mathrm{Ca} \\
(\mathrm{mM})\end{array}$} & \multirow[b]{2}{*}{ \pm} & \multirow{2}{*}{$\underset{(\mathrm{mM})}{\Sigma S}$} & \multirow[b]{2}{*}{ \pm} \\
\hline & Top & Bottom & & & & & & & & & & & & & & & & \\
\hline \multicolumn{19}{|c|}{ 340-U1395B- } \\
\hline $1 \mathrm{H}-3$ & 4.40 & 4.50 & 3.6 & 7.7 & 554.1 & & 36 & 0.01 & 470.5 & 2.9 & 54.0 & 0.6 & 10.8 & 0.2 & 10.4 & 0.1 & 28.4 & 0.3 \\
\hline $2 \mathrm{H}-3$ & 10.30 & 10.40 & 3.4 & 7.5 & 558.7 & & 37 & 0.02 & 481.6 & 10.3 & 54.0 & 0.1 & 11.3 & 0.3 & 10.2 & 0.1 & 28.0 & 0.4 \\
\hline $3 \mathrm{H}-5$ & 22.70 & 22.80 & 5.6 & 7.4 & 555.3 & & 37 & 0.67 & 485.6 & 4.5 & 52.9 & 0.4 & 10.7 & 0.2 & 7.8 & 0.0 & 24.3 & 0.6 \\
\hline $4 \mathrm{H}-3$ & 29.32 & 29.42 & 7.5 & 8.0 & 559.2 & & 36 & 0.84 & 485.3 & 3.7 & 52.0 & 0.4 & 10.3 & 0.1 & 7.7 & 0.1 & 23.7 & 0.2 \\
\hline $4 \mathrm{H}-6$ & 33.88 & 33.98 & 6.0 & 7.5 & 568.3 & & 37 & 0.89 & 488.1 & 3.3 & 52.3 & 0.3 & 10.2 & 0.2 & 8.4 & 0.1 & 24.0 & 0.3 \\
\hline $5 \mathrm{H}-3$ & 38.80 & 38.90 & 6.4 & 9.7 & 567.7 & & 37 & 0.96 & 482.5 & 3.8 & 50.6 & 0.4 & 10.4 & 0.2 & 8.9 & 0.1 & 23.9 & 0.3 \\
\hline $6 \mathrm{H}-4$ & 49.72 & 49.82 & 6.4 & 8.9 & 571.9 & & 37 & 1.03 & 482.6 & 2.9 & 50.8 & 0.3 & 10.0 & 0.1 & 8.9 & 0.1 & 24.1 & 0.4 \\
\hline $6 \mathrm{H}-6$ & 52.85 & 52.95 & 7.0 & 7.7 & 571.4 & & 37 & 1.05 & 482.4 & 2.5 & 51.0 & 0.3 & 9.8 & 0.1 & 8.9 & 0.1 & 24.2 & 0.3 \\
\hline $7 H-4$ & 59.31 & 59.41 & 6.1 & 8.0 & 568.8 & & 37 & 1.05 & 487.3 & 1.4 & 51.7 & 0.1 & 9.7 & 0.1 & 8.9 & 0.0 & 24.3 & 0.0 \\
\hline $9 \mathrm{H}-1$ & 72.60 & 72.70 & 5.4 & 7.4 & 571.2 & & 37 & 1.09 & 485.2 & 3.2 & 51.6 & 0.5 & 9.1 & 0.1 & 9.2 & 0.1 & 24.9 & 0.3 \\
\hline $10 \mathrm{H}-2$ & 82.30 & 82.40 & 5.6 & 7.5 & 570.2 & & 37 & 1.10 & 498.3 & 1.5 & 52.6 & 0.3 & 8.9 & 0.0 & 9.8 & 0.0 & 26.1 & 0.2 \\
\hline $10 \mathrm{H}-5$ & 86.81 & 86.91 & 5.2 & 7.2 & 568.5 & & 37 & 1.11 & 485.5 & 4.4 & 51.4 & 0.4 & 8.5 & 0.2 & 9.3 & 0.1 & 25.3 & 0.2 \\
\hline $11 \mathrm{H}-3$ & 92.10 & 92.20 & 5.5 & 7.5 & 571.5 & & 37 & 1.11 & 487.6 & 2.6 & 51.3 & 0.3 & 8.5 & 0.1 & 9.6 & 0.1 & 25.2 & 0.0 \\
\hline $12 \mathrm{H}-3$ & 101.15 & 101.25 & 5.4 & 7.4 & 568.5 & & 37 & 1.15 & 488.9 & 2.9 & 51.3 & 0.5 & 8.1 & 0.2 & 9.8 & 0.1 & 25.3 & 0.2 \\
\hline $12 \mathrm{H}-6$ & 105.70 & 105.80 & 5.2 & 7.3 & 568.2 & 2.6 & 37 & 1.15 & 486.5 & 1.7 & 50.9 & 0.3 & 8.0 & 0.2 & 9.8 & 0.1 & 25.1 & 0.2 \\
\hline $13 \mathrm{H}-4$ & 112.02 & 112.12 & 5.1 & 7.3 & 568.9 & & 36 & 1.18 & 497.3 & 11.6 & 50.5 & 0.9 & 7.9 & 0.1 & 10.2 & 0.2 & 25.0 & 0.3 \\
\hline $14 \mathrm{H}-3$ & 117.30 & 117.40 & 5.3 & 7.7 & 571.5 & & 37 & 1.21 & 502.7 & 13.8 & 50.7 & 0.9 & 7.9 & 0.2 & 10.7 & 0.2 & 25.6 & 0.4 \\
\hline $24 X-1$ & 185.50 & 185.60 & 5.5 & 7.2 & 567.5 & & 37 & 1.21 & 503.7 & 13.7 & 44.0 & 0.7 & 6.9 & 0.0 & 14.1 & 0.2 & 24.6 & 0.2 \\
\hline $25 X-1$ & 195.10 & 195.20 & 5.4 & 7.1 & 570.4 & 0.4 & 37 & 1.14 & 487.3 & 2.8 & 42.5 & 0.9 & 6.4 & 0.1 & 14.3 & 0.2 & 23.9 & 0.7 \\
\hline
\end{tabular}

One $\mathrm{Cl}$ value of $505.7 \mathrm{mM}$ for Section 340-U1395B-1H-3 was not used because part of the sample was dropped. One value for Section $10 \mathrm{H}-2$ was not used for calculation of the average, as this sample was atypically high ( $\mathrm{Na}=569 \mathrm{mM}, \mathrm{Mg}=59.6 \mathrm{mM}, \mathrm{K}=10.1 \mathrm{mM}, \mathrm{Ca}=11.1 \mathrm{mM}$, and $\mathrm{S}=28.7 \mathrm{mM}$ ). Uncertainties for $\mathrm{Cl}$ represent $\pm 1 \sigma$ based on duplicate analyses. Shaded samples represent average values for $\mathrm{Na}, \mathrm{Mg}, \mathrm{K}, \mathrm{Ca}$, and $\Sigma \mathrm{S}$ (total sulfur) from duplicate analyses from separate runs. Shaded $\mathrm{pH}$ values are particularly high and are considered suspect. Samples in italics represent averages from within-run duplicates. 
Table T4. Correlation point picks and depth shifts, Hole U1395B.

\begin{tabular}{rrr}
\hline $\begin{array}{c}\text { Original } \\
\text { depth } \\
\text { (mbsf) }\end{array}$ & $\begin{array}{c}\text { Corrected } \\
\text { depth } \\
\text { (mbsf) }\end{array}$ & $\begin{array}{c}\text { Difference } \\
(\mathrm{m})\end{array}$ \\
\hline 2.488 & 2.393 & 0.095 \\
3.819 & 3.195 & 0.624 \\
6.299 & 6.276 & 0.023 \\
8.730 & 8.861 & -0.131 \\
13.642 & 12.730 & 0.912 \\
14.294 & 13.045 & 1.249 \\
14.784 & 14.153 & 0.630 \\
15.466 & 16.601 & -1.135 \\
17.067 & 17.584 & -0.517 \\
17.854 & 18.259 & -0.405 \\
18.405 & 19.379 & -0.974 \\
19.143 & 19.977 & -0.834 \\
20.191 & 21.835 & -1.643 \\
20.547 & 22.216 & -1.669 \\
23.912 & 23.763 & 0.149 \\
25.026 & 24.701 & 0.325 \\
25.715 & 25.437 & 0.278 \\
26.387 & 26.193 & 0.194 \\
29.292 & 28.262 & 1.030 \\
32.829 & 32.014 & 0.815 \\
34.208 & 33.397 & 0.811 \\
37.229 & 36.728 & 0.501 \\
40.406 & 39.395 & 1.011 \\
40.997 & 40.039 & 0.958 \\
42.814 & 41.648 & 1.167 \\
43.094 & 41.882 & 1.212 \\
44.946 & 44.210 & 0.736 \\
45.245 & 44.835 & 0.409 \\
45.406 & 45.047 & 0.359 \\
45.841 & 45.489 & 0.351 \\
46.591 & 46.244 & 0.347 \\
51.396 & 49.949 & 1.447 \\
52.258 & 50.825 & 1.433 \\
52.723 & 51.672 & 1.050 \\
53.194 & 52.309 & 0.885 \\
55.055 & 54.318 & 0.736 \\
55.398 & 54.444 & 0.954 \\
& &
\end{tabular}

\begin{tabular}{|c|c|c|}
\hline $\begin{array}{l}\text { Original } \\
\text { depth } \\
\text { (mbsf) }\end{array}$ & $\begin{array}{l}\text { Corrected } \\
\text { depth } \\
\text { (mbsf) }\end{array}$ & $\begin{array}{l}\text { Difference } \\
\quad(\mathrm{m})\end{array}$ \\
\hline 57.486 & 56.704 & 0.783 \\
\hline 58.179 & 57.601 & 0.578 \\
\hline 60.960 & 58.829 & 2.131 \\
\hline 62.300 & 60.153 & 2.147 \\
\hline 63.215 & 60.865 & 2.350 \\
\hline 65.319 & 62.315 & 3.005 \\
\hline 66.244 & 63.445 & 2.799 \\
\hline 66.734 & 64.016 & 2.718 \\
\hline 67.849 & 66.139 & 1.710 \\
\hline 68.239 & 66.708 & 1.531 \\
\hline 71.314 & 69.901 & 1.413 \\
\hline 72.740 & 71.311 & 1.430 \\
\hline 73.156 & 71.921 & 1.235 \\
\hline 76.628 & 73.812 & 2.816 \\
\hline 78.069 & 75.217 & 2.852 \\
\hline 79.148 & 76.155 & 2.993 \\
\hline 79.521 & 76.588 & 2.933 \\
\hline 79.928 & 77.310 & 2.618 \\
\hline 80.270 & 77.839 & 2.431 \\
\hline 80.818 & 78.546 & 2.273 \\
\hline 82.009 & 80.341 & 1.668 \\
\hline 83.095 & 82.665 & 0.430 \\
\hline 83.282 & 82.857 & 0.425 \\
\hline 85.791 & 84.839 & 0.952 \\
\hline 87.002 & 85.993 & 1.008 \\
\hline 88.375 & 88.149 & 0.227 \\
\hline 89.678 & 89.228 & 0.450 \\
\hline 91.191 & 90.483 & 0.709 \\
\hline 92.613 & 92.028 & 0.585 \\
\hline 95.698 & 94.886 & 0.812 \\
\hline 99.100 & 96.691 & 2.409 \\
\hline 103.995 & 102.555 & 1.440 \\
\hline 106.882 & 105.530 & 1.352 \\
\hline 110.857 & 109.860 & 0.998 \\
\hline 113.216 & 112.217 & 1.000 \\
\hline 114.699 & 115.582 & -0.883 \\
\hline 115.340 & 116.592 & -1.252 \\
\hline
\end{tabular}


Table T5. Samples measured for paleomagnetism, Site U1395.

\begin{tabular}{|c|c|c|}
\hline Core & Measured & $\begin{array}{c}\text { APC } \\
\text { core barrel }\end{array}$ \\
\hline \multicolumn{3}{|c|}{ 340-U1395A- } \\
\hline $1 \mathrm{H}$ & Yes & Standard \\
\hline $2 \mathrm{H}$ & Yes & Nonmagnetic \\
\hline $3 \mathrm{H}$ & Yes & Nonmagnetic \\
\hline $4 \mathrm{H}$ & Yes & Nonmagnetic \\
\hline $5 \mathrm{H}$ & Yes & Nonmagnetic \\
\hline $6 \mathrm{H}$ & Yes & Nonmagnetic \\
\hline $7 \mathrm{H}$ & Yes & Nonmagnetic \\
\hline $8 \mathrm{H}$ & Yes & Nonmagnetic \\
\hline $9 \mathrm{H}$ & Yes & Nonmagnetic \\
\hline $10 \mathrm{H}$ & Yes & Standard \\
\hline $11 \mathrm{H}$ & Yes & Standard \\
\hline $12 \mathrm{H}$ & Yes & Standard \\
\hline $13 \mathrm{H}$ & Yes & Standard \\
\hline $14 \mathrm{H}$ & Yes & Standard \\
\hline $15 \mathrm{H}$ & Yes & Standard \\
\hline $16 \mathrm{X}$ & No sample & \\
\hline $17 X$ & Core catcher & \\
\hline $18 \mathrm{X}$ & Yes & \\
\hline $19 X$ & Core catcher & \\
\hline $20 x$ & Core catcher & \\
\hline $21 X$ & Yes & \\
\hline $22 x$ & Yes & \\
\hline $23 x$ & Yes & \\
\hline $24 X$ & Core catcher & \\
\hline $25 X$ & Yes & \\
\hline $26 \mathrm{X}$ & Yes & \\
\hline $27 X$ & Yes & \\
\hline $28 x$ & Yes & \\
\hline \multicolumn{3}{|c|}{ 340-U1395B- } \\
\hline $1 \mathrm{H}$ & Yes & Standard \\
\hline $2 \mathrm{H}$ & Yes & Nonmagnetic \\
\hline $3 \mathrm{H}$ & Yes & Nonmagnetic \\
\hline $4 \mathrm{H}$ & Yes & Nonmagnetic \\
\hline $5 \mathrm{H}$ & Yes & Nonmagnetic \\
\hline $6 \mathrm{H}$ & Yes & Nonmagnetic \\
\hline $7 \mathrm{H}$ & Yes & Nonmagnetic \\
\hline $8 \mathrm{H}$ & Yes & Nonmagnetic \\
\hline $9 \mathrm{H}$ & Yes & Nonmagnetic \\
\hline $10 \mathrm{H}$ & Yes & Nonmagnetic \\
\hline $11 \mathrm{H}$ & Yes & Standard \\
\hline $12 \mathrm{H}$ & Yes & Standard \\
\hline $13 \mathrm{H}$ & Yes & Standard \\
\hline $14 \mathrm{H}$ & Yes & Standard \\
\hline $15 \mathrm{H}$ & Yes & Standard \\
\hline $16 \mathrm{X}$ & Yes & \\
\hline $17 X$ & Core catcher & \\
\hline $18 \mathrm{X}$ & Core catcher & \\
\hline $19 X$ & Yes & \\
\hline $20 x$ & Yes & \\
\hline $21 X$ & Shorter than response function & \\
\hline $22 X$ & Yes & \\
\hline $23 x$ & Core catcher & \\
\hline $24 X$ & Yes & \\
\hline $25 X$ & Yes & \\
\hline
\end{tabular}

$\mathrm{APC}=$ advanced piston corer 